\title{
The Evolution and Diffusion of the Standard Business Reporting (SBR) Initiatives: Evidence from UK Small Businesses
}

Said M. Alkhatib. School of Business, The University of Jordan, Jordan, s_khatib@ju.edu.jo

Esraa S. Alkhatib. School of Business, Al-Zaytoonah University of Jordan, Jordan, e.alkhatib@zuj.edu.jo

\begin{abstract}
Few studies have comprehensively described Standard Business Reporting (SBR) as a policy-driven initiative based on inline eXtensible Business Reporting Language (iXBRL) aimed at reducing the administrative burden of statutory business reporting. The SBR term is still difficult to understand even by the countries where it has been implemented. The objective of this study is twofold. First, it describes in detail the evolution of the SBR initiatives in the UK. Second, it investigates the drivers and inhibitors of the take-up of the SBR initiative by small businesses based on the technology, organization, and environment (TOE) framework. It draws on contextual data and 23 interviews with participants involved in the development of these initiatives. The findings show that the following are perceived as drivers of the take-up of the SBR initiatives by small private companies: the relative advantages of using WebFiling, commercial filing software, and the digital services, the organizational accountant's readiness, and the influence of commercial filing software. However, we find no evidence that the relative advantage of using the joint-filing facility via iXBRL was perceived as a driver of the take-up of this innovation. The findings indicate that the absence of critical mass among government agencies inhibits its diffusion. This study provides specific implications to small businesses, the accountants working in small businesses and practice, government agencies in the UK, and other jurisdictions embarking on the SBR initiatives for further developments to reduce the reporting burden on smaller entities.
\end{abstract}

Keywords: Small business, Standard Business Reporting, TOE framework, the UK, XBRL, inlineXBRL. 


\section{INTRODUCTION}

This paper provides a comprehensive analysis of the evolution of SBR initiatives in the UK. It also investigates the drivers and inhibitors of SBR by small businesses. The role of small businesses is vital in the UK economy. ${ }^{1}$ The recent statistics by the Department for Business, Energy, and Industrial Strategy (BEIS) showed that there were $6 \mathrm{~m}$ small businesses, representing $99.3 \%$ of the total UK businesses. They generated $36 \%$ of turnover and $48 \%$ of jobs in the UK (BEIS, 2020). According to the Organization for Economic Cooperation and Development (OECD) definition, SBR is a policy-driven initiative to reduce reporting burden and compliance costs (OECD, 2009). It is based on international open standards, such as eXtensible Business Reporting Language (XBRL) (Ojala et al., 2018). XBRL allows companies to file one set of information instead of filing it repeatedly in different forms to different government agencies (Sinnett \& Wallis, 2009). XBRL also facilitates the transmission of structured data between businesses and governmental agencies and allows information to be re-used easily (Ojala et al., 2018).

SBR requires creating a national taxonomy that represents a 'data dictionary' aiming to provide a single set of definitions and language for the information reported by businesses to the government (Madden, 2009). The taxonomy allows the data to be tagged in a standard way through a common government gateway and drives out duplicated data and unnecessary descriptions (Azam \& Taylor, 2013), thus reducing the reporting burden on businesses (KPMG, 2006). It has been described as a 'postal office' that allows businesses to file their standardized reports once to multiple governmental agencies (OECD, 2009). The taxonomy can be developed for a specific jurisdiction or industry within a specific country (Troshani \& Rao, 2007).

The vision of SBR/XBRL has been successfully rolled out in several countries (Lim $\&$ Perrin, 2014). Since 2004, the Netherlands has been the first country to introduce SBR. By 2007 all listed companies were allowed to use the Dutch SBR taxonomy for filing their financial reports immediately from their filing software to three government agencies: the tax authority; the statistics office; and the chamber of

\footnotetext{
${ }^{1}$ A reporting entity qualifies typically as small under sections 382 to 384 of the Companies Act 2006 and FR 102 if it is nonpublicly accountable and does not exceed two of three size tests in the financial year concerned and the preceding year: annual turnover is up to $£ 10.2 \mathrm{~m}$; balance sheet total $£ 5.1 \mathrm{~m}$; the number of employees is up to 50 . The financial thresholds shown here are those in force at the time of the study. Available at: https://uk.frs $102 . c o m / b l o g /$ frs- 102 -section-1a-quickguide/.
} 
commerce (Sinnett \& Willis, 2009). Subsequently, Australia, Finland, New Zealand, Belgium, Singapore, India, China, the USA, Canada, and the UK have also developed their SBR programs, building on the lessons learned from the Netherlands (OECD, 2009; Ojala et al., 2018; Robb et al., 2016). Our focus in this study is on two SBR initiatives developed in the UK: The first initiative exhibits the digital filing mediums consist of WebFiling, commercial filing software, and joint filing services. Small businesses can use these mediums to file statutory accounts and annual returns from small businesses to Companies House $(\mathrm{CH})$. Once the digital statutory accounts and annual returns are filed through these mediums, they are published via the $\mathrm{CH}$ website. By doing so, $\mathrm{CH}$ provides open and free digital services on its website to enable Internet users the use of other companies' accounts and returns. These digital services represent the second initiative that include digital company search and data services.

A considerable amount of literature has been published on XBRL-based reporting. Few studies, however, attempted to comprehensively describe the SBR initiative as a policy-driven one based on XBRL, even by those countries where it has been implemented. Some studies recommended that further research be carried out as the SBR term is still somewhat clumsy to understand (Miller, 2013; Lim \& Perrin, 2014). The innovation diffusion literature (see Appendix A) has focused on the adoption of SBR via XBRL in the Netherlands, Australia. However, their findings were limited for two reasons: First, the factors that drive and inhibit SBR adoption often differ across countries. Different national taxonomies have been developed based on different regulatory reporting regimes and accounting standards (Deshmukh, 2004). Second, most of these studies focused on XBRL adoption by large listed companies or government agencies, and little or no research has focused on small companies.

On the other hand, few studies provided evidence of the costs and benefits of XBRL-based reporting (see Appendix B). However, none of them focused on developing the joint-filing facility via iXBRL, especially after the use of iXBRL was expected to be mandated by the European Security and Market Authority (ESMA) for a single electronic reporting format (ESEF) in 2020 (ESMA, 2020; 2021). We seek to further our understanding of the development of the SBR initiatives in the UK. Its setting is of particular interest in the European and international context, where joint-filing via iXBRL has been implemented in the 
UK between $\mathrm{CH}$ and HM Revenue and Customs (HMRC). Therefore, the objectives of this UK study are twofold:

- To provide a comprehensive analysis of evolution of the SBR initiatives in the UK.

- To investigate the drivers and inhibitors of SBR by small businesses based on the technology-organization-environment (TOE) framework.

The remainder of the study is structured as follows. We review the literature in the following section. We then describe the methodology and provide a detailed description of the evolution of the SBR initiatives in the UK. Next, we present and discuss the findings of our empirical evidence. The study closes by concluding and providing some implications to practice and suggesting avenues for further research.

\section{LITERATURE REVIEW}

The technology-organization-environment (TOE) framework was developed by Tornatzky and Fleischer (1990), and it is considered as an important theoretical perspective for identifying specific contextual factors at an organizational level. The contextual factors representing these three aspects are technology, organization, and environmental contexts, which may influence organizational adoption of technology innovations (Tornatzky \& Fleischer, 1990).

The technological context refers to the characteristics of both internal and external technologies relevant to an organization (Tornatzky \& Fleischer, 1990). Internal technologies are those currently adopted by the organization, and external technologies represent technologies existing in the marketplace but are not used by the organization (Al-Hujran et al., 2018). Technological factors in IT studies are often drawn from the Diffusion of Innovations (DOI) theory developed by Rogers in 1983 (Oliveria \& Martins, 2011). According to the DOI theory, the technological characteristics of the innovation are: "relative advantage, compatibility, complexity, observability, and trialability" (Rogers, 1995, p. 211). Several IT studies found that combing this theory with the TOE framework is very useful for understanding the costs and benefits of the technology (Daoud, 2019). The organizational context describes an organization's characteristics and resources that determine the adoption of innovative technology (Oliveria \& Martins, 2011). They determine the adoption of innovative technology, including firm size, top 
management support, organization structure and culture, and the availability of human and financial resources (Oliveria \& Martins, 2011). The environmental context represents the external arena in which a company conducts its business, industry, competitors, and dealings with the government (Tornatzky \& Fleischer, 1990). The external relationships with those parties may influence adoption decisions (Tornatzky \& Fleischer, 1990).

Having reviewed IS literature, the TOE framework has been widely employed and tested by many IS studies, thus generating consistent empirical support (Zhu et al., 2006). Twelve studies on XBRL-reporting are based on the TOE framework to investigate the factors that determine its adoption, and they are summarized in Appendix A. This confirms the validity and usefulness of this framework in improving the understanding of the diffusion of complex IS innovations in general, (Zhu et al., 2006) and XBRL reporting in particular (Lim \& Perrin, 2014). Thong (1999) showed that it could be expanded to add further new factors to enhance our understanding of technology adoption (Thong, 1999). Following the above reasons, this study was based on the TOE framework to structure the findings on the drivers and inhibitors of taking up SBR by UK small businesses.

\section{RESEARCH METHOD}

The study is designed under a broadly interpretivist paradigm. This paradigm adopts a range of methods that "seek to describe, translate and otherwise come to terms with the meaning, not the frequently of certain more or less naturally occurring phenomena in the social world" (Van Maanen, 1979, p. 9). Under interpretivist research, the findings are not derived from the statistical analysis of quantitative data (Corbin \& Strauss, 2008; Collis \& Hussey, 2013). Two methods were employed to collect our data: The first method was from the contextualization to collect secondary data from the relevant SBR literature, publications, recommendations, reports, publicly available documents, and other materials available at organizations' websites. The organizations involved in developing the SBR initiatives in the UK are OECD, HMRC, CH, XBRL international, XBRL UK, FRC, ACCA, and ICAEW. This method was chosen to describe the evolution of the SBR initiatives in the UK that will be discussed in Section 4.

The second method was by conducting interviews to collect primary data from the participants involved in the SBR evolution and are discussed in Section 5. The interviews have provided new insights and in-depth information about the drivers 
and inhibitors of the take-up of the SBR by small businesses in the UK. The first method secondary data supplements the interview data. By collecting data from different sources, we used data triangulation which reduces bias in the data source (Jick, 1979; Easterby-Smith et al., 2012).

\subsection{Sample selection}

Twenty-one participants were selected to be interviewed from the key stakeholders' groups. Previous studies in the UK on XBRL reporting identified that the key stakeholder groups are: accountants and auditors, tax professionals, and users of financial information (Cox, 2006; Dunne et al., 2013). They were affected by or can influence the decision to adopt the SBR initiatives in the UK. The details of the interviews conducted are presented in Appendix C. The interviews with participants are conducted in two stages:

Stage I: sixteen participants were interviewed in 2016. The initial contact was made with interviewees at $\mathrm{HMRC}, \mathrm{CH}$, and two accountants from accountancy firms while participating in the 5th Brunel Accounting Symposium in London during Summer 2016. The Symposium was a one-day event organized by the Accounting and Auditing Research Centre (AARC) at Brunel Business School, which aimed to promote discussion on contemporary issues in digital accounting, provide continuing professional development, and foster relationships with regulators and the accounting profession. One interview was held with the assistant manager at HMRC; one with the head of digital accounts at $\mathrm{CH}$; one with external consultants of HMRC digital filing; two accountants from commercial filing software providers; seven qualified accountants from accountancy firms; four qualified accountants from three small businesses in the UK. Both accountants who were working in accountancy firms recommended other accountants at the end of each interview. Consequently, we used a snowball sample to identify new interviewees.

Stage II: Five participants were interviewed in 2021. We contacted the participants in the first stage, fourteen of those contacted either declined or failed to respond to the request to participate. We received an automatic email showing that the failure to receive replies to the outgoing emails was caused by messages delivered to unmonitored mailboxes. Some interviewees may have a conscious decision not to participate in the study. Only two accountants agreed to participate again in the follow-up interviews. They also recommended further three qualified accountants and provided us their contact details. One interview was held with a qualified 
accountant from accounting software vendors, two with qualified accountants working in small businesses, and two with qualified accountants was working in practice and had at least one small businesses client. The findings from this stage were to validate and test our findings from the first stage.

The two participants from government agencies in the first stage confirmed that accountants in small business and practice represent most of those filing digital business information at $\mathrm{HMRC}$ and $\mathrm{CH}$. Interviewee 1 from HMRC illustrated this point clearly, by stating: "The professional accountants currently file almost $85 \%$ of digital reports for small companies". Interviewee 2 from $\mathrm{CH}$ agreed with Interviewee 1 by saying: "At least $70 \%$ of all accounts coming to us are generated by the accountant". Our evidence showed that the accountants are currently using the digital data services available at the $\mathrm{CH}$ website. Therefore, all qualified accountants were asked two sets of questions as they are involved in developing the SBR initiatives in two ways. The first set of questions were designed for filers of the statutory accounts and returns and the second for those using the digital services at the $\mathrm{CH}$ website. The findings are based on eighteen views from filers and twentyone views from digital services users. A relatively good level of saturation was reached and achieved at sixteen interviews with the filers. As Vasileiou et al. (2018) recommended, the saturation level is reached where the further interview cannot identify any additional issues and new insights.

\subsection{Interviews}

All interviews in two stages were semi-structured. The interview questions were open-ended as their answers will be longer and will provide more details. They also enabled the respondents to think and allowed the researcher to obtain further information about the phenomena (Collis \& Hussey, 2014). We added some probes to collect in-depth insights and a new understanding of digital filing by small firms. As Flick (2002) recommended, the interview questions list was sent before one week to the interviewees to give them enough time to think and provide the answers based on their experiences. The critical incident technique was used to encourage the interviewee to tell their story based on their experience.

The interviews were based on a qualitative research protocol. They mainly discussed the relative costs and benefits of digital filing and the main factors that may drive and inhibit the take-up of the SBR initiatives in the UK. The interviews in the first stage took place between June and October 2016. Ten of them were face- 
to-face, and six were by telephone. Every interview lasted approximately 45 minutes. Some interviews were recorded and transcribed. The participants received a copy of the transcripts to obtain their approval. The interviews in the second stage took place in September 2021. All of them were by telephone and lasted from 20 to 30 minutes. In the second stage, we sent a summary of the main findings from the first stage to the accountants by email before one week to capture the similarities and differences in their views after 2016. The interviewees were then asked to comment on them and suggest any further modifications, including new issues between 2016 and 2021. We updated some of our findings to include the changes mentioned during the follow-up interviews. For example, the annual return was recently replaced by a 'confirmation statement' by $\mathrm{CH}$. The old joint-filing facility at $\mathrm{CH}$ and free HMRC software filing were replaced and named the 'CATO' platform between $\mathrm{CH}$ and HMRC.

\subsection{Data analysis}

The data were analyzed thematically, aided by NVivo 10.0, a qualitative data analysis software. It can reduce many manual tasks and enable the researcher to derive themes and analyze the data efficiently (Bazeley \& Jackson, 2013). Thematic analysis refers to a "method for identifying, analyzing, and reporting patterns (themes) within data, and it helps in organizing and describing the qualitative data in detail" (Braun \& Clarke, 2006, p. 6). This method was widely used by several studies on SBR/XBRL literature, as shown in Appendix A. It has three main advantages: firstly, it is easy to learn and no need to have experienced before analyzing the data. Secondly, it helps in describing and summarizing key findings of big data sets systematically. Thirdly, it enables the researcher to find the similarities and differences across the data set and highlight new insights (Miles \& Huberman, 1994; Braun \& Clarke, 2006; Bryman \& Bell, 2015).

The interviews were analyzed by taking five steps to analyze the interview data, as Miles and Huberman (1994) recommended. First, the data was read and re-read several times to familiarize the researcher with the data. Second, the data was coded by creating labels (or nodes) to some words, phrases to capture new issues. These codes helped in classifying our data into sub-categories with a common characteristic. Third, all codes were allocated into the specific theme(s), and some comments and reflections were added using memos. Fourth, the codes were derived based on the TOE framework. Fifth, new themes were developed and then 
presented in order of importance attached by the interviewees. Both authors analyze the data. Together, these steps helped in addressing the construct validity of our findings (Collis \& Hussey, 2014). As this study was conducted based in the UK context, we cannot ensure its external validity. All important quotes are presented in the following findings and discussion section.

\section{THE EVOLUTION OF SBR INITIATIVES IN THE UK}

Figure 1 demonstrates a pre-SBR architecture in the UK situation where businesses must file multiple statutory annual reports, accounts, and returns in different data formats to the same or different governmental agencies (OECD, 2009). Some of the reports contain the same information with different descriptions. It was very difficult to address this issue with paper-based reporting (OECD, 2009). Although various types of information technologies have been employed by businesses to meet their compliance with governmental agencies, none drives out all duplicated data and unnecessary descriptions of files and documents.

Several studies suggested two scenarios to implement the SBR initiatives (OECD, 2009; Hulstijn et al., 2011; Eierle et al., 2014): The first scenario is shown in Figure 2, called "One-stop shop" architecture. All statutory business reports are filed through a "common gateway" to multiple government agencies, as shown in Figure 2. These agencies can also re-use the data (Hulstijn et al., 2011). This scenario is also described as a multiple reporting model since multiple reports are still required to be filed from businesses to multiple agencies. The second scenario is displayed in Figure 3 that demonstrates a "Store once, report many" architecture where businesses need to store their statutory businesses reports once in a standard format which can generate multiple reports and send them to multiple government agencies. Although the users can re-use the company's report data over different reporting chains, the actual act of reporting remains specifically addressed to one agency (Bharosa et al., 2011).

These scenarios' architectures describe two different forms of SBR. As shown in Figure 2, UK businesses can send multiple business reports through this gateway to multiple government agencies; these multiple reports, therefore, lack standardization. 


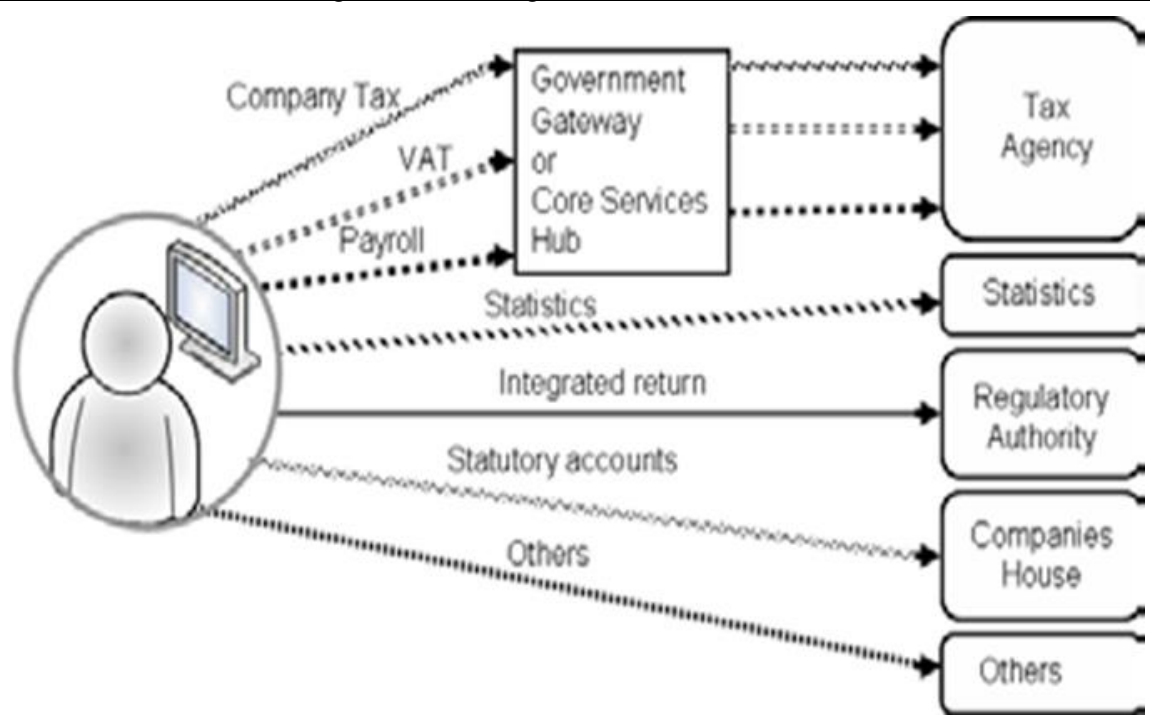

Figure 1. Pre-SBR architecture in the UK (Source: OECD $(2009$, p. 8))

On the other hand, Bharosa et al. (2011) argued that the "one-stop-shop" scenario could be too far-reaching because legislation might not allow re-using data collected for one purpose to be used for different purposes. In contrast, the second form of SBR in Figure 3 addresses these issues by using one standard report (or few reports) that could be sent through the gateway to multiple government agencies. The gateway is expected to be managed by "Logius" in choosing which business reports will be routed to a specific. ${ }^{2}$ The gateway also carries out other services such as authentication, logging, validation, etc.

In 2005, the Hampton Report was commissioned by a regulatory system to reduce administrative burdens on business. It mentioned that 'there are too many, often overlapping forms and data requirements with no scheme to reduce their number' (Hampton, 2005, p. 7). The Carter Report (2006) then recommended that HMRC and $\mathrm{CH}$ collaborate to develop SBR services for filing financial reporting and returns.

In response, the UK government developed two SBR initiatives that affect mainly micro and small businesses: First, the provision of digital filing of statutory company accounts and returns at $\mathrm{CH}$.

\footnotetext{
${ }^{2}$ Logius term is often used in the Netherlands that refers to the digital government service of the Netherlands Ministry of the Interior and Kingdom Relations to maintain smart ICT solutions and common standard available at www.loguis.nl.
} 


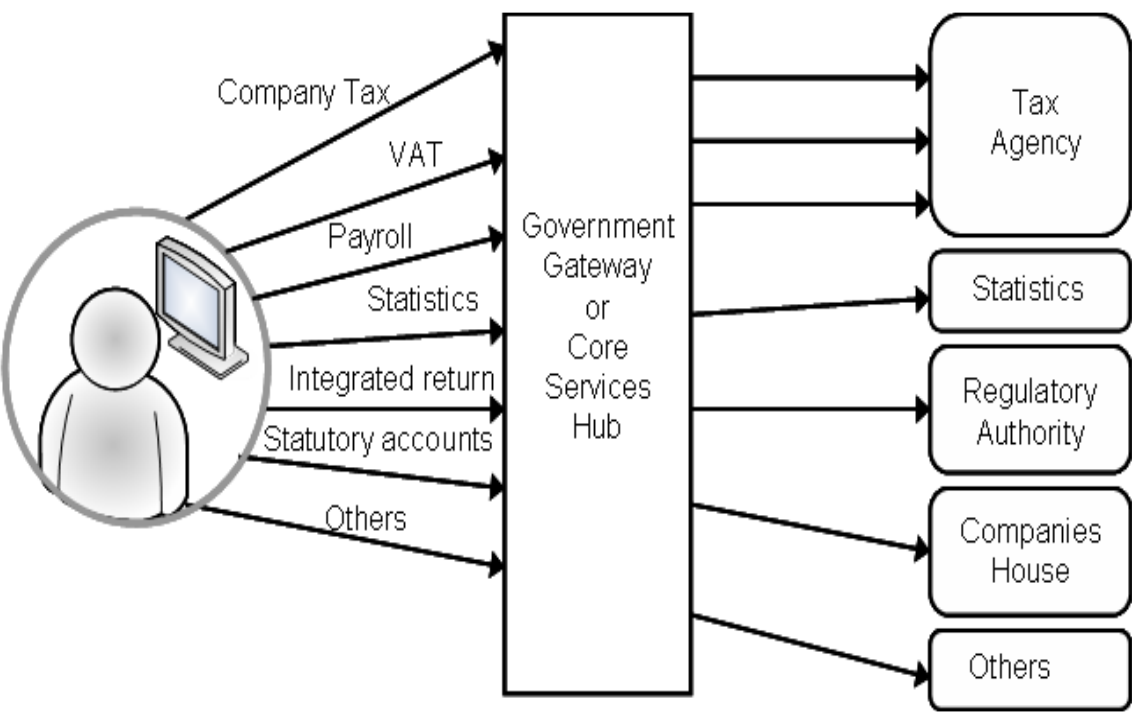

Figure 2. Multiple reporting model (Source: OECD (2009, pp.8))

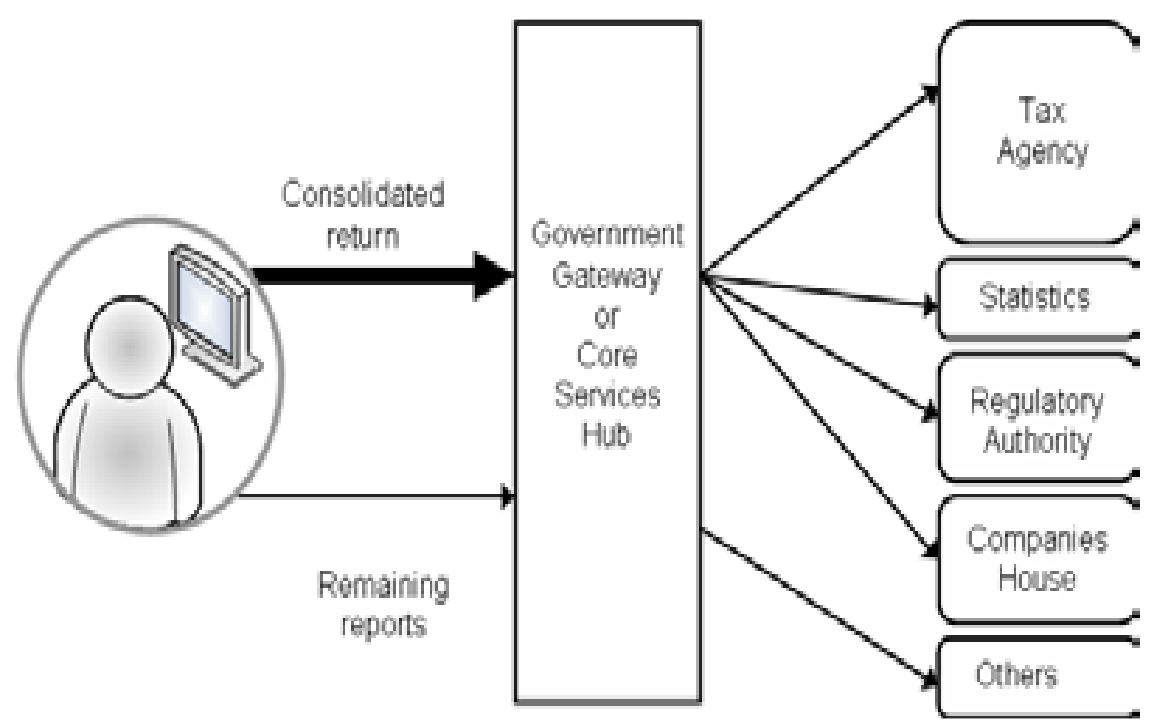

Figure 3. The Proposed SBR architecture in the UK (Source: OECD (2009, pp. 10))

The rationale was that digital filing would improve the performance of the administrative and data processing tasks of $\mathrm{HMRC}$ and $\mathrm{CH}$ and would reduce costs and administrative burdens on small businesses (KPMG, 2006; HMRC, 2009). Second is the introduction of digital services to improve the accessibility of free open data to users (Companies House, 2013). 
Although SBR has been described repetitively in many web-based governmental reports, most descriptions are either clumsy or difficult to understand (Lim \& Perrin, 2014). This study focused on these two SBR initiatives currently developed in the UK to simplify and summarize the current SBR situation, as shown in Figure 4. The first SBR initiative is illustrated on the left side of Figure 4, which exhibits the digital filing mediums for filing the statutory accounts and annual returns available for UK small businesses. These mediums consist of WebFiling, commercial filing software, and joint filing services. In the middle, HMRC and $\mathrm{CH}$ are particularly chosen as these governmental agencies are currently participating in the development of SBR. The second SBR initiative represents the digital services encompassing digital company search and data services on the right side. The details of each initiative are described in the following sub-sections.

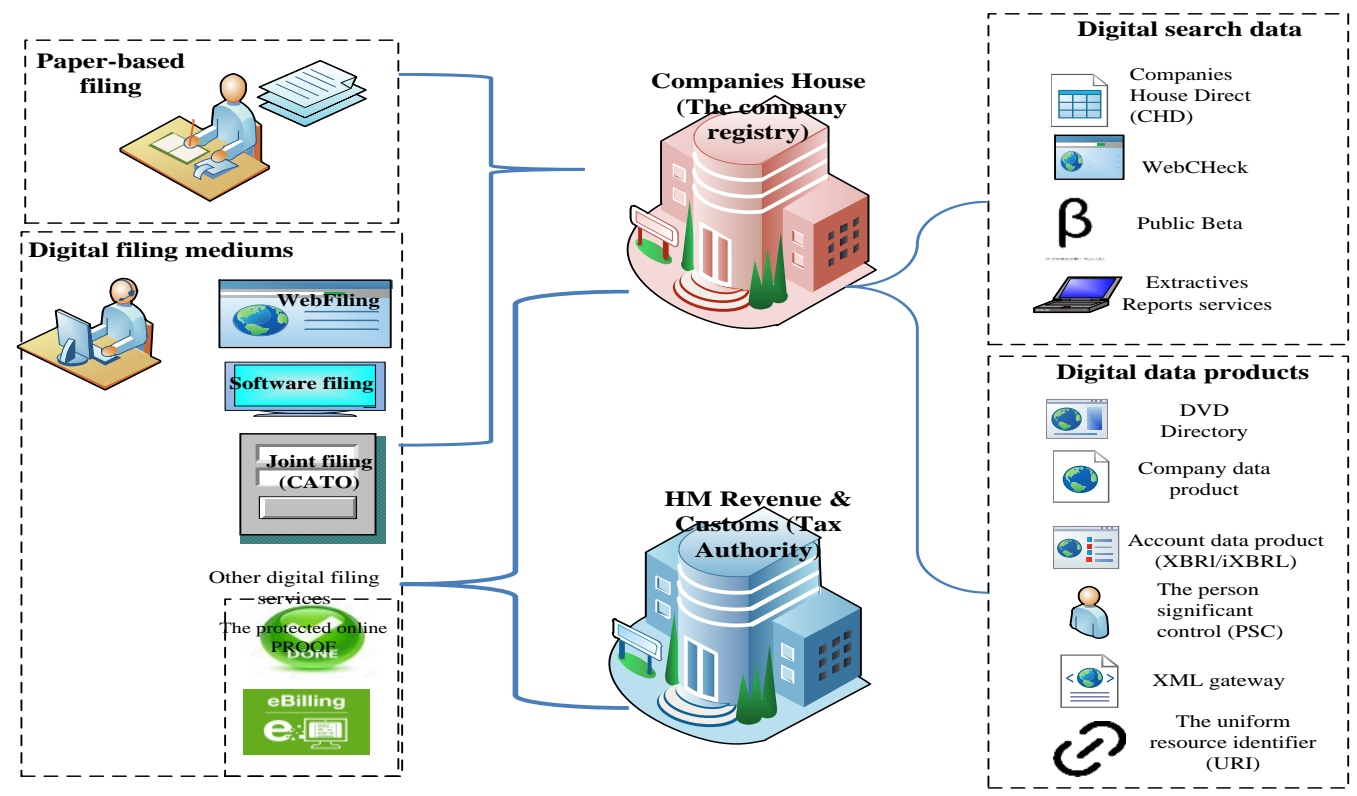

Figure 4. Simplified the current SBR situation in the UK

\subsection{First SBR initiative: Digital filing mediums}

In 2005, XBRL was granted full approval for digital filing of the corporation tax returns at HMRC (HMRC, 2009). The corporation tax returns include company tax forms (CT 600), corporation tax computations, and statutory accounts (Collis et al., 2018). The year after, $\mathrm{CH}$ also moved to the digital filing of statutory accounts and 
annual returns (Mousa, 2013a). At present, only small companies are voluntary file their statutory accounts and annual returns in digital format. ${ }^{3}$

Small businesses in the UK are allowed to use four different mediums to file their statutory accounts and annual returns with $\mathrm{CH}$ :

1. Traditional paper-based filing

2. Commercial filing software

3. WebFiling Service

4. Joint-filing between $\mathrm{CH}$ and HMRC

All companies must file their statutory accounts and annual returns with $\mathrm{CH}$ and they can choose either by the traditional paper-based reporting or using digital filing mediums (Companies House, 2013). As the traditional paper-based reporting suffers from manual processing, entry chores and many filing errors, companies in the UK moved to use the electronic mediums such as CD-ROM. Although such mediums were faster and less expensive than paper reporting in distributing large amounts of business information between different stakeholders, they are still distributed by physical means (Lymer et al., 1999). The emergence of the firstgeneration digital reporting addresses these issues and shortcomings of the electronic mediums (Lymer \& Debreceny, 2003). The first generation represents the first level of Internet reporting whereby businesses can converting their information into Portable Document Format (PDF) or HyperText Mark-Up Language (HTML), and then able to disseminate their reports online (Debreceny \& Gray, 1999). The stakeholders, therefore, can access the business information efficiently on the Internet (Adams \& Frost, 2004). HTML files can easily extract and retrieve information. However, HTML files are difficult to print, save, or convert into other formats to conduct further analysis (Lymer et al., 1999).

The evolution of second-generation digital reporting takes digital reporting a step further by standardizing the data using open standard and structured format (Dunne et al., 2009). This next generation is underpinned by an eXtensible mark-up language (XML) and its subset XBRL (ICAEW, 2004). XML (and hence XBRL)

\footnotetext{
${ }^{3}$ https://informi.co.uk/business-administration/how-do-i-file-my-company-accountsmkm
} 
enables information to be tagged in a standardized manner to capture numbers and the meaning of the information (Doolin \& Troshani, 2007). The tags provide a wide range of information for each item in the financial reports, such as a definition, description, unit of measurement, and mathematical relationships between the accounts (Plumlee \& Plumlee, 2008). Unlike the first generation, XBRL is fully multi-lingual, an important consideration for business reporting. The XBRL tags facilitate translating financial reports into a wide variety of languages (Lymer et al., 1999). The move towards XBRL also offers two major advantages: firstly, it removes the manual intervention of the information supplied by companies, and secondly, it drives out duplicated business information that is filed to multiple government agencies.

The digital statutory accounts filed by small companies at Companies House are dormant, abbreviated audit exempt, full audit exempt, and full audited accounts (Companies House, 2013). The annual digital returns give general information about the company's directors, secretary (if applicable), registered office address, shareholders, and share capital (ICAEW, 2010). After 2016, the annual return with $\mathrm{CH}$ was replaced by the confirmation statement under the Small, Business, Enterprise and Employment Act 2015. The confirmation statement contains the same required information in the annual return and requires more details about persons of significant control (PSC). The PSC refers to any person who holds the right to exercise significant influence or control over a small company, such as appoint or remove a director or employee(s) of the company. ${ }^{4}$ Since $2007, \mathrm{CH}$ announced that many commercial filing software packages were approved and enabled to facilitate digital filing by small businesses (Mousa, 2013b). The following year, WebFiling was introduced to offer simple, downloadable web forms to provide benefits to the filers, such as savings on postage, 24/7 availability, and improved security (Companies House, 2013). It allows small businesses to submit audited full, audit exempt abbreviated or full accounts or dormant accounts (if applicable) (Companies House, 2015).

All companies in the UK are required to file the same information twice to fulfill their statutory obligations to HMRC and $\mathrm{CH}$. Both government agencies introduced the joint filing facility in 2011 to provide a 'one-stop-shop' for micro and small businesses. This facility enables them to submit audit-exempt full accounts

\footnotetext{
${ }^{4}$ https://www.quickformations.com/guides/person-of-significant-control/
} 
simultaneously to HMRC and CH (Alkhatib et al., 2019). The expected benefits of using joint-filing were: time-saving, cost-cutting of £60m for $\mathrm{HMRC}$ and $\mathrm{CH}$, and driving out duplicated information, and reducing the number of errors in the filing process resulting from paper-based filing (BIS, 2009). Overall, it reduces the reporting burden to government agencies (OECD, 2009).

While joint-filing had been developed, small companies faced one important issue: the small companies with abbreviated accounts that filed with $\mathrm{CH}$ were required to file their full accounts to HMRC at the same time (Mousa, 2011). The XBRL standard was unable to absorb a large amount of information on such accounts. This technical issue was the most important reason behind the move from XBRL to inline XBRL (iXBRL) in the UK (Troshani et al., 2015). IXBRL report can generate a series of both the Hypertext Markup Language (HTML) and extended HTML (XHTML) documents; ixbrl, thus, can absorb a large amount of information filed by small businesses. For example, small businesses can use the iXBRL document to file their full accounts with HMRC, the profit and loss account, and the balance sheet file the abbreviated balance sheet with $\mathrm{CH}$ simultaneously.

The second advantage of $\mathrm{iXBRL}$ over XBRL is that $\mathrm{XXRL}$ can present information in a machine-readable and human-readable format. In contrast, XBRL can present it only in a machine-readable format. Thus, the company's information in XXBRL format is presented in what looks like a normal document but with embedded XBRL tags (Eierle et al., 2014). In 2010, iXBRL was used for the submission of CT600 accounts and computations at HMRC. It has been mandatory for most companies for accounting periods ending after 31 March 2010, regardless of size, and tax payments must be made electronically in iXBRL format with HMRC (HMRC, 2010).

Since 2015 HMRC and $\mathrm{CH}$ have developed a new joint filing service called Company Accounts and Tax Online (CATO). It replaced the old free HMRC filing software developed for the small companies with relatively straightforward financial affairs to file their corporation tax returns jointly with $\mathrm{CH}$.

By using CATO service, the micro and small entities have three filing options:

1. Submit the company tax return (CT600) online to HMRC.

2. Submit the company accounts to $\mathrm{CH}$. 
3. Submit the company tax return and company accounts to HMRC and Companies House at the same time.

The "digital by default" principle has been adopted by $\mathrm{CH}$ that commits to increase the take-up percentage of digital filing between 2014 and 2020 (Companies House, 2015). By 2015, CH received information digitally for more than $85 \%$ of the accounts and returns filed by companies online (Companies House, 2015). At the end of 2017, the statistics indicate that almost 2.2 million small businesses filed their statutory business information either in XBRL or iXBRL format voluntarily to $\mathrm{CH}$ for meeting their corporate reporting requirements (FRC, 2017).

In the UK situation, the WebFiling and commercial filing software mediums are similar to that of the multiple reporting model of SBR illustrated in Figure 2, in which small businesses still file their multiple statutory accounts and returns via XBRL/iXBRL to HMRC and $\mathrm{CH}$ separately. In contrast, the joint filing medium represents the SBR form shown in Figure 3. The same statutory accounts and returns are filed once by small businesses with HMRC and $\mathrm{CH}$ simultaneously. Small businesses also can use other digital filing mediums such as the protected online PROOF service and eBilling portal. The PROOF service is a free service that helps them protect their information filed by WebFiling or software filing from unauthorized and fraudulent changes. eBilling portal helps small entities to manage the credit accounts they have electronically with $\mathrm{CH}$ instead of making their payments by post. Once the statutory accounts and annual returns are filed from small businesses to $\mathrm{CH}$ through digital filing mediums, they are published on the $\mathrm{CH}$ website. The website offers open and free digital services to enable the use of other companies' XBRL/iXBRL data that will be explained in the next subsection.

\subsection{Second SBR initiative: Digital services at the $\mathrm{CH}$ website}

Since 2007, CH has engaged with the transformational government program in line with the government's commitment to offering free public data to Internet users by providing digital services (Companies House, 2008). CH introduced digital services and migrated its website content to the GOV.UK website between 2008 and 2013 (Companies House, 2013). In 2014, CH started its new strategy for providing digital services based on two new principles. First, $\mathrm{CH}$ replaced old digital services to provide simpler and better new digital services to Internet users. Second, $\mathrm{CH}$ is now offering open and free corporate data to Internet users and improving the accessibility of that data (Companies House, 2015). By 2016, the $\mathrm{CH}$ website 
announced two main digital services that enable companies to use other companies' digital data: ${ }^{5}$ Company search services and data services, as shown on the right side of Figure 4, and their descriptions are presented in Table 4. By February 2021, Companies House Service (CHS) was expected to replace both Companies House Directory (CHD) and WebCHeck services. It offers a searchable index of millions of companies' names, numbers, or officer names. It enables users free access to change a registered office address, view company data and document images, search for disqualified directors, order certificates and certified documents, and follow companies. Nevertheless, the closure decision of WebCHeck and CHD has been delayed later 2021. ${ }^{6}$

$\begin{array}{|lll|}\begin{array}{l}\text { Types of } \\ \text { digital } \\ \text { services }\end{array} & \begin{array}{l}\text { Digital } \\ \text { services } \\ \text { subgroups }\end{array} & \end{array}$

\footnotetext{
${ }^{5}$ https://www.gov.uk/guidance/companies-house-data-products

${ }^{6} \mathrm{https} / / / \mathrm{www}$.gov.uk/government/news/companies-house-direct-and-webcheck-services-to-close-later-in-2021
} 


\begin{tabular}{|c|c|c|}
\hline \multirow[t]{6}{*}{$\begin{array}{l}\text { Digital } \\
\text { data } \\
\text { products }\end{array}$} & DVD Directory & $\begin{array}{l}\text { Provides basic company details on } 3 \mathrm{~m} \text { live companies } \\
\text { registered in the UK, as well as companies that have been } \\
\text { dissolved during the previous month. There is a } \\
\text { subscription fee of } £ 30 \text { per month }\end{array}$ \\
\hline & Company data & $\begin{array}{l}\text { - It is a free downloadable data snapshot that is provided as } \\
\text { ZIP file that contains basic company data as comma- } \\
\text { separated values (CSV) for live companies on the } \\
\text { Register. }\end{array}$ \\
\hline & $\begin{array}{l}\text { Accounts data } \\
\text { (XBRL/iXBRL) }\end{array}$ & $\begin{array}{l}\text { - It is a free downloadable ZIP file that comprises the } \\
\text { individual data files of the company accounts in iXBRL or } \\
\text { XBRL. } \\
\text { The most recent accounts can be downloaded from the } \\
\text { daily files available in the CH website, whilst historical } \\
\text { accounts are available from the previous year's monthly } \\
\text { files. } \\
\text { Up to date, approximately } 60 \% \text { of the } 2.2 \text { million accounts } \\
\text { are filed in XBRL/iXBRL formats each year }\end{array}$ \\
\hline & $\begin{array}{l}\text { The people with } \\
\text { significant } \\
\text { control(PSC) }\end{array}$ & $\begin{array}{l}\text { - It is a free downloadable data snapshot that is provided in } \\
\text { JavaScript Object Notification (JSON) format file that } \\
\text { contains details of person who has significant control over } \\
\text { accompany. } \\
\text { The significant control or influence includes ownership of } \\
\text { shares, voting rights, the right to appoint or remove } \\
\text { directors }\end{array}$ \\
\hline & $\begin{array}{l}\text { Companies } \\
\text { House XML } \\
\text { gateway }\end{array}$ & $\begin{array}{l}\text { - It is a gateway that offers electronic access to a core range } \\
\text { of company records using eXtensible Mark-up language } \\
\text { Enables documents to be submitted electronically to } \mathrm{CH} \\
\text { using softwarefiling. There is a subscription fee of } £ 4.7 \\
\text { per month }\end{array}$ \\
\hline & $\begin{array}{l}\text { The uniform } \\
\text { resource } \\
\text { identifier (URI) }\end{array}$ & $\begin{array}{l}\text { It is a free unique web address for each company which } \\
\text { helps access to basic company details using the company' } \\
\text { URI }\end{array}$ \\
\hline
\end{tabular}

Table 4. The types of digital services provided by $\mathrm{CH}$ and their descriptions

\section{FINDINGS AND DISCUSSION}

\subsection{Technological context}

Based on our analysis, the relative advantage of the SBR initiative is considered a major driver to the take-up of the SBR initiatives among UK small businesses. Relative advantage refers to "the perceived costs and advantages involved in the adoption of an innovation, mostly in terms of economic return, but also in terms of immediacy of reward, social prestige, or savings in time and effort" (Rogers, 1995, p.216). In IT innovation studies, the relative advantage is commonly expressed in economic terms of a perceived cost/benefit analysis (Doolin \& Troshani, 2007). In 
this study, we divided the findings related to the relative advantage of the SBR initiative into two sub-themes: first, the relative advantage of using digital filing mediums by the filers to produce and file statutory accounts and annual returns for small companies. The digital filing mediums include a joint filing facility, WebFiling service, and commercial filing software. Second, the relative advantage of using digital services includes company search data and digital data services for those using other companies' XBRL/iXBRL data provided by $\mathrm{CH}$. By doing so, our evidence takes a coherent approach to the overall standardization benefits of SBR to filers and users of digital accounts and returns for small businesses in the UK.

\subsubsection{Relative advantage of digital filing mediums}

As discussed earlier, most of the filers of the statutory accounts and annual returns in digital formats are accountants in small businesses and practice. They were first asked about their choice to use digital filing mediums to file the statutory accounts at $\mathrm{CH}$ and company tax returns at HMRC. They were then asked about their perceptions of the benefits and costs of selected digital filing mediums they usually use, as discussed below.

\subsubsection{The relative advantage of joint filing}

Our interviews data in 2016 revealed that only two accountants in business and one accountant in practice made use of the joint filing facility (or CATO service). They used it only upon their client's request to file their accounts and annual returns once to HMRC and $\mathrm{CH}$ simultaneously. However, none of them reported any advantage of using a joint filing facility over WebFiling and commercial filing software. Although two accountants are aware of this facility, none of the accountants interviewed in 2021 have used this service to file digital accounts and returns for their small companies or on behalf of their small business clients.

Three possible barriers restrict using the joint filing facility (CATO service) by the filers. First, it is only designed for micro and small businesses exempt from filing audited accounts and has straightforward tax affairs. The types of statutory accountants that can be filed using joint filing are dormant; abbreviated, audit exempt; small full, audit exempt accounts. Small businesses, therefore, will be unable to file their full audited accounts using this service. This finding was supported by interviewee 18, who said: "A CATO service is not for everyone. It is designed for small companies with abbreviated accounts and tax agents are 
specifically prohibited from using it. If your company is large, the financial accounts require auditing. If you have more complicated tax affairs, you have to rely on commercial filing software by $i X B R L$ vendor to do the filing of accounts and corporation tax returns".

Second, small companies with two different digital filing deadlines with HMRC and $\mathrm{CH}$ are excluded from using this service. Small businesses could file their tax returns and accounts only for the same accounting periods once at $\mathrm{HMRC}$ and $\mathrm{CH}$, respectively. Interviewee 2 raised this issue by saying: "If we are asking companies to file iXBRL with us, this means small businesses have to tag their accounts up to three months earlier than required at HMRC." Interviewee 1 confirmed this issue by saying: "there are still different requirements for using joint filing. They (companies) must make changes in their business reports and then file them separately. It's time-consuming and expensive". The two different filing deadlines are related to both Company Act and tax law, and, therefore, the digital filing deadlines do not concur. Since 2005, the Taxes Act has required UK businesses to submit their statutory business and accounting information to HMRC within 12 months of the accounting year-end (Companies House and HM Revenue \& Customs, 2005). At the same time, they have a statutory obligation by the Company Act 2006 to file their statutory businesses and accounting information with $\mathrm{CH}$ within nine months of the accounting year-end (Companies House, 2013).

Third, the tax agents and external accountants are not allowed by HMRC to use this service on behalf of their clients. Based on our interviews in 2021, interviewee 17 mentioned that: "Since 2015, HMRC announced that the current corporation tax (CT) online filing form would be retired and replaced with a new basic online tool. HMRC is working together with Companies House on a new free online improved facility called Company Accounts and Tax Online (CATO). It will be no longer available for tax agents who are filing on companies' behalf. Smaller entities are required to access using their credentials [company ID and password at HMRC Gateway]". These barriers inhibit the accountants in practice and tax agents from using this service and drive them to use the other alternatives mediums that are WebFiling and software filing on behalf of their small companies' clients. Nevertheless, although these mediums overcome all these barriers, multiple statutory reports and forms are still being sent from small businesses to HMRC and $\mathrm{CH}$ separately. 
These findings indicated a lack of awareness about the advantage of this facility as it is based on iXBRL standards. IXBRL is developed to facilitate statutory filing accounts and annual returns at $\mathrm{HMRC}$ and $\mathrm{CH}$ simultaneously by re-using the same reports several times (Eierle et al., 2014). This advantage has mainly remained unproven. Thus, the diffusion of this facility will not occur among small businesses and their accountants.

\subsubsection{The relative advantage of WebFiling and software filing mediums}

Most accountants in business and practice often use other digital filing mediums, including commercial filing software and WebFiling. There was a consensus that using WebFiling service or commercial filing software offers three major benefits: costs and time-saving, convenience, and accuracy. For example, interviewee 12 observed that: "The process of filing digital accounts takes from few minutes to sometimes a couple of hours, depending on the accounts type, but paper filing takes up to two weeks to be processed into our system." Another support by accountant 15 commented: "XBRL filing is much faster and cheaper. The paper returns cost $£ 40$ while the filing e-returns would cost $£ 13$ at $C H$ ”. Accountants 6 also mentioned that: "You get errors with paper filing as it relies on humans' intervention, but electronic accounts are much more accurate than paper." This finding supports previous studies on XBRL-based reporting (Doolin \& Troshani, 2007; Pinsker \& $\mathrm{Li}, 2008)$

Surprisingly, all of the accountants interviewed believed that the costs of the commercial filing software to produce digital documents are low, and they thus are no longer a burden on small businesses. Interviewee 12 confirmed this finding by saying: "The cost to produce iXBRL documents is not an issue for small companies as the commercial software options are available, simple. They are inexpensive. We normally pay less than $£ 1,000$ a year to renew our annual license...”. Eleven accountants mentioned that the commercial filing software would cost between hundreds and thousands of British pounds. For example, Interviewee 5 stated: "Filing small accounts with HMRC has changed. It first started with a lot of manual tagging because iXBRL software was quite expensive. The commercial market of the software becomes less expensive for iXBRL products". It indicates that the availability of ready-to-use and low-cost commercial filing software products facilitates the take-up of the SBR initiatives. The finding contradicts those in previous research on XBRL in the UK (Dunne et al., 2013) and Australia (Lim \& 
Perrin, 2014), where the cost of commercial filing software was high, negatively affecting the adoption by large businesses.

\subsubsection{Relative advantage of digital services}

The interviewees were first asked whether they use digital services to access other companies' data (as depicted in Figure 4). Our data showed the most of accountants interviewed frequently used WebCHeck, CHD and beta service. They were then asked about their perceptions of the quality of digital data provided by these digital services at the $\mathrm{CH}$ website. Most accountants reported that these digital services make the companies' accounts and data more accessible than paper-based reporting. The reason is that the digital iXBRL format offers continuous and faster access to the company's data and reduces the cost of acquiring the information. Interviewee 1 stated that: "I can directly access and use the company's business reports and then compare them across years and with other companies in the same industry. The computer can process that tagged information at the time that the report is received. So you can look at it, and you can access it any time". Some accountants mentioned that digital reports in iXBRL enhanced the usefulness of the digital data at the $\mathrm{CH}$ website. IXBRL or XBRL provides more reliable information due to fewer filing errors, offers a clear definition of each component of the accounts, and enhances the comparability of digital information. However, they had no opinion that these services may enhance the efficiency of their investment decision-making or enhance their understanding of the different elements of the digital accounts provided at the $\mathrm{CH}$ website. These findings are similar to those of several studies on SBR/XBRL, where XBRL enhances the accuracy and comparability of business information based on a standardized taxonomy (Baldwin et al., 2006; Vasarhelyi et al., 2012; Eierle et al., 2014).

Lim and Perrin (2014) argued that although the quality of accounts and data in XBRL format is an important factor for the long-term success of the SBR in Australia, it has hardly been mentioned or discussed in the literature. The interviewees from $\mathrm{HMRC}$ and $\mathrm{CH}$ raised this issue related to the quality of tagged data in digital formats. Interviewee 1 mentioned: "One of the issues we had is how we can be assured about the quality of the reports tagged in $i X B R L$... The only way to answer the question is to go and sit behind the business while they are filing to examine the quality of tagging. To date, we cannot answer this question well, 'What is the quality of the tagging?". Our explanation for this issue is that the quality of 
the reports filed in digital format to $\mathrm{HMRC}$ and $\mathrm{CH}$ depends largely on the quality of filing software used by the filers. Some commercial filing software provides poor-quality reports. Bartley et al. (2010) and Debrecency et al. (2010) argued that the inappropriate treatment in documents of underlying debit/credit assumptions in the taxonomy might cause tagging errors in the USA.

Nevertheless, none of the accountants interviewed in 2021 addressed this issue when using the $\mathrm{CH}$ digital services. We expected that this is because $\mathrm{CH}$ recently offered the XBRL/iXBRL Online Validation Service for small companies with audit-exempt accounts. This service is developed to enable the filers of statutory accounts and returns to test their submissions for conformance with iXBRL taxonomy. ${ }^{7}$ Small companies with full audited accounts are excluded from using this tagging validation tool. Their auditors can conduct assurance service to their XBRL/iXBRL-based documents before the final submission to $\mathrm{CH}$. Several studies suggested that using the XBRL tagging validation tool could help perform an iXBRL assurance (Boritz \& No, 2003; Plumlee \& Plumlee 2008; Srivastava \& Kogan, 2010).

\subsection{Organization context}

The analysis of data showed that the organizational accountant's readiness was perceived as a driver of the take-up of the SBR initiative among UK small businesses. Organizational readiness refers to the availability of financial and human resources in-house to drive the company to adopt new technology (Tornatzky \& Fleischer, 1990). As mentioned before, accountants represent most of those filing digital statutory accounts and returns at HMRC and $\mathrm{CH}$. The accountants were asked how small businesses in the UK normally manage the process of digital filing their statutory accounts and annual returns to $\mathrm{CH}$ and HMRC. Most of them pointed out that the digital filing process is entirely managed in-house in most small businesses, while a small minority outsource it with external accountants. This finding is inconsistent with a long history of UK studies that concluded that most small businesses depend on an external accountant for filing their paper-based financial reporting (Collis et al., 2018). Thus, accountants in businesses play an important role in using digital filing for small companies.

\footnotetext{
${ }^{7}$ https://ewf.companieshouse.gov.uk/xbrl_validator
} 
The data from interviews suggested three indications of the accountants' readiness to use the digital filing mediums at $\mathrm{CH}$. Firstly, all accountants in business considered the familiarity with the use of e-applications (e.g., e-banking and einvoicing with customers or suppliers) as an important motivator to use digital filing for small businesses. Secondly, they are familiar with digital filing at HMRC as it has been mandated since 2011. For example, interviewee 2 said: "Although the regime is still voluntary, small entities file their electronic accounts since they used to do the same filing with HMRC, and it costs nothing to file with us." From the filers' perspective, eight of the accountants agreed with this finding. Interviewee 8 confirmed that: "The failure to submit the accounts with $\mathrm{CH}$ successfully could be attributed to inexperience to do it at HMRC." Lymer et al. (2012) also suggested that most of the tax agents of SMEs already have an online habit and are ready to use further digital filing services. Thirdly, the accountants highlighted that digital filing does not require in-house special technical training or expertise or more specialized training to file business information in XBRL/iXBRL formats. The most of them received some self-training and used online tutorials to learn about using digital filing. Interviewee 4 stated: "Very little technical expertise is essential to file SME accounts because the software package is very handy in creating the necessary iXBRL documents. The filers are required to have different accounting skills because all digital reports are automatically completed. Any web browser then can display them." Interviewee 2 further explained this finding by saying: "Most people have no idea about what XBRL means and how it works. It is the technology underneath the e-filing package, so they don't need to be bothered about it". In contrast, Doolin and Troshani (2007) found that adopting XBRL filing in Australia requires special technical expertise in-house. A plausible justification for our different findings is that HMRC simplified tagging business information by allowing the filers to use the minimum tagging list based on the UK taxonomies (HMRC, 2013).

Most accounts filed at $\mathrm{CH}$ are abbreviated audit exempt; most of the accountants in small businesses can file those accounts to $\mathrm{CH}$. Thus, the accountants in businesses (in-house) play a more effective role in the diffusion of the SBR initiatives than those in practice (outsource) in filing digital accounts and returns in small companies. The different images emerged from the accountants in practice perspectives. Most of them reported the importance of the accountancy firms' role in taking the SBR initiative by sharing their successful experiences with their 
clients. Interviewee 8 indicated: "We advised our clients to use simple Web-Filing templates last year, we submitted more than $2 \mathrm{~m}$ iXBRL documents, representing more than $40 \%$ of all outsourced submissions and this made our clients more confident about filing online". Interviewee 17 supported this perspective by saying: "At the beginning of 2012, our clients asked us to file their accounts online, in particular small entities. These days we do not accept any request to file paper accounts from the clients".

\subsection{Environment context}

\subsubsection{Influence from the commercial filing software providers}

The interviews data showed that the influence of the commercial filing software providers drives the take-up of the SBR initiatives in the UK. For instance, interviewee 13 noted: "Our manager decided to file the documents online after one of their vendor representatives visited our site. They have well-trained experts who are dealing with $\mathrm{iXBRL}$ filings daily since 2014". Commercial filing software providers are active in marketing their digital products in the UK. They are also active in running training and workshops to help the filers use the digital filing of the business information. Interviewee 7 stated that: "After I had received some vendor training on XBRL technology and attended some useful and free workshops, I found the process of filing is much easier because I can jog my memory on numerous occasions." Our finding is new and inconsistent with previous studies in Australia (Troshani \& Rao, 2007; Lim \& Perrin, 2014). There was a lack of filing software providers' support and limited XBRL applications and tools. They argued that this might lead to organizational resistance and inhibit the SBR initiative's adoption in Australia. In contrast, our evidence showed that the most of the filers of digital business information are more likely to use commercial filing software. It, perhaps, reflects that the commercial filing software is highly advanced and affordable that drives small businesses to adopt XBRL or iXBRL to file their information with $\mathrm{CH}$ and HMRC.

\subsubsection{Critical mass}

The findings revealed that a limited critical mass hinders the diffusion of the SBR initiative in the UK. Unless there is a critical mass of adopters and stakeholders, technological innovation has little advantage of being adopted by a potential organization (Rogers, 1995). The existence of a critical mass provides potential new 
adopting organizations with the availability and the facility to access external support and information (Heeks, 2006; Tornatzky \& Fleischer, 1990).

The first interviewee at HMRC was asked about his perception of the advantage of SBR in sharing iXBRL data with potential new governmental agencies after 2016; he replied: "We did not do SBR in the UK. I don't understand why it has not been taken up anymore. You can see this cooperation in Australia and the Netherlands today. In the UK, companies have to produce accounts and send those accounts to $\mathrm{CH}$ and HMRC. So, there was a huge incentive for HMRC and CH to cooperate, which I would say has been done very successfully, but it's a bit strange that there is less cooperation with other agencies. We began talking to the Bank of England and other agencies that might be interested in XBRL, but it doesn't seem that they are ready to do it. I think SBR will happen if the businesses come to the government and say we want this to benefit us. Could you please provide us? It is not something that the government is looking to impose on the business community." This comment reflects the "wait-and-see game" found in Australia and occurs between the filers and users of XBRL reports. It demonstrates that the filers will not produce XBRL-based reports unless the users require these reports, and users will not require XBRL-based reports unless filers can make them available (Doolin \& Troshani, 2007). A different picture emerged in the case of $\mathrm{CH}$; interviewee two commented: "We are working with a few government agencies on the possibility for implementing SBR using XBRL/iXBRL. The candidates are the Department of National Statistics, the Charity Commission, and a possibility with the Department of Education. We are working closely to make sure that we all have the same standard".

There is a lack of government agencies' engagement to take up the SBR initiative. It, therefore, has been still slow in the UK since 2016. Three barriers might inhibit the diffusion of SBR among governmental agencies. Two of the barriers are associated with the "one-stop-shop" scenario adopted and implemented in the UK. It enables the business information to be provided once to a single-entry point, and then multiple governmental agencies can re-use it once needed (OECD, 2009). Nevertheless, Bharosa et al. (2011) noted that this scenario involves two issues: Firstly, legal constraints of sharing the data between multiple governmental agencies. This issue was reported by interviewee five, who claimed: "HMRC was slow to develop and even understand the idea of sharing data with $\mathrm{CH}$.... It would 
be a legal constraint. We cannot say for the citizens that we have some data, would you like it? We have to make sure that legally we can do so". As the legislation will not allow the filers using of data for different purposes, this scenario would be too far-reaching.

The second barrier is the lack of standardization of the business reports filed from businesses to the government because they still have different functions and may therefore have different contents. Mahler and Rogers (1999) argued that one of the main characteristics that may hinder technological innovations from reaching; would critical mass is the lack of standardization. The standardized reports format removes the need to re-key data manually, which facilitates the efficient re-use of the same data by multiple government agencies for different purposes (Ojala et al., 2018). It also reduces transaction costs and facilitates economies of scale through interchangeability between systems (Kindleberger, 1983). Without widespread adoption among stakeholders, the benefits of standardization arising from the use of the innovation are lost (Zhu et al., 2006).

The third barrier is a lack of knowledge and awareness among the stakeholders about the idea of SBR via iXBRL. The most important advantage of the iXBRL standard is enabling the filers of business information to re-use the data efficiently in the reporting supply chain (Eierle et al., 2014). Alternatively, we suggest that moving from the "one-stop-shop" scenario to the proposed "store once, report many" scenario (illustrated in Diagram 2 and 3 respectively, Section 4) could address these issues as suggested in the report by OECD (2009). Multiple reports would be standardized into a single, or few reports can be sent through the gateway to multiple government agencies. The gateway is expected to be managed by "logius" that maintains comprehensive ICT solutions and common standards for a government, which helps choose which business reports will be routed to a specific agency. The Dutch government chose this scenario in implementing the SBR initiative in 2006.

\section{CONCLUSION}

This paper investigates the evolution and diffusion of the SBR initiatives via inline XBRL by small businesses in the UK based on the TOE framework. 
Drawing on collecting triangulated data by using the contextual and qualitative methods, the findings provide new insights and contribute to the innovation diffusion literature on SBR in three ways:

First, this research provides a comprehensive analysis of the evolution of the SBR initiatives in the context of the UK. Some studies call for future research to simplify the idea behind of SBR initiative (Bharosa et al., 2011; Lim \& Perrin, 2014). Our study fills in this gap. Second, it enhances the knowledge of the overall relative advantage of the SBR initiative that can be classified into two types: the first relative advantage is from using voluntary digital filing mediums that include joint-filing facility and WebFiling and software filing to file the accounts and returns from small companies to $\mathrm{CH}$. The second relative advantage is that digital services include company search data and digital data services for those using other companies' digital data at the $\mathrm{CH}$ website. By doing so, our evidence provides a holistic view of the overall standardization benefits of SBR for small businesses in the UK. Third, our findings demonstrate the TOE framework's applicability and usefulness in studying SBR innovation diffusion among small entities. Unlike the SBR/XBRL literature that mainly focused on large listed companies, we investigate the drivers and inhibitors of the take-up of the SBR initiatives for UK small businesses.

In the technological context, the accountants perceived the relative advantages of using WebFiling and commercial filing software as a driver of the take-up of the SBR. However, we found no evidence that they perceived the relative advantage of using the joint-filing facility as a driver of the take-up of this innovation. To date, there is a lack of knowledge about its advantage, and the accountants should extensively use this facility to perceive its advantage. The idea behind using this service is simple, instead of filing the duplicate statutory accounts and returns with $\mathrm{HMRC}$ and $\mathrm{CH}$, it enables the filers to re-use the same statutory reports in iXBRL format with both agencies simultaneously. Unless this relative advantage is unproven, the diffusion of this innovation will not occur among the accountants. Further, we found that it is restricted to be used for specific types of small accounts and returns, with the same filing deadlines at $\mathrm{HMRC}$ and $\mathrm{CH}$, and is not allowed to be used by the tax agents and external accountants. Together, these restrictions, perhaps, inhibit the filers from using this service and drive them to use other digital filing mediums alternatives like WebFiling and commercial filing software. 
Although these alternatives overcome all the restrictions, they failed to offer the relative advantage of the joint filing facility as multiple statutory reports and forms are still being sent from small businesses to HMRC and $\mathrm{CH}$ separately. We also found the costs of the commercial filing software to produce digital documents are low, and they thus are no longer a burden on small businesses in the UK. Our analysis also demonstrated that most accountants perceived relative advantage of digital services such as WebCHeck, $\mathrm{CHD}$, and and beta service at the $\mathrm{CH}$ website.

In the organizational context in the TOE framework, our findings suggested that the organizational accountant's readiness in small businesses is considered a driving factor of the take-up of the SBR initiatives at $\mathrm{CH}$. Most small businesses manage the digital filing process in-house, whereas a small minority outsource it with external accountants in most small businesses. Most of the accountants in business already have an online habit as they are ready and familiar with the use of mandatory digital filing mediums with HMRC and other e-applications. We also found that digital filing at $\mathrm{CH}$ does not require special technical training, expertise in-house, or more specialist training because iXBRL/ XBRL is the technology that underpins the accounting filling software and is not visible to the filers. Since most accounts filed at $\mathrm{CH}$ are abbreviated audit exempt, the accountants in businesses (in-house) play a more influential role in the diffusion of the SBR initiatives than those in practice (outsource) in filing digital accounts and returns in small companies. In the environmental context in the TOE framework, our analysis identified three factors that affect the adoption of SBR initiatives: (a) the influence of commercial filing software providers and (b) limited critical mass.

Our findings provide further implications for practice and policymakers: firstly, accountants in business and practice are in the best business position to advise on digital filing mediums. Secondly, HMRC and $\mathrm{CH}$ should work together to remove the current barriers that restrict using the joint filing facility. They also should collaborate with other stakeholders (e.g., regulatory agencies, XBRL UK Consortium, accountancy professions) to increase the consciousness about the joint filing platform and its benefits among the accountants. We also suggested that publishing a business case for small companies, organizing seminars, and other training workshops on using and importance of the joint filing with both agencies may increase the awareness of its benefits among the accountants in practice and small businesses. Thirdly, we recommended that moving from the "one-stop-shop" 
scenario to the "store once, report many" scenario (illustrated in Diagram 3) could address the standardization and legal issues encountered from the first scenario. Lastly, the UK government should extend the current scope of the SBR by including more business reports, different businesses size, and other government agencies involved in the SBR initiatives. By doing so, businesses will perceive more standardized benefits from the SBR initiatives.

The major limitation of our study is related to our small sample that is insufficient to generalize the findings to the entire population. We conducted only 21 interviews with participants from $\mathrm{HMRC}, \mathrm{CH}$, and qualified accountants involved in developing the SBR initiatives in the UK. However, we based on 39 views: 18 filers and 21 users of digital information as the accountants use digital filing mediums to file statutory accounts and returns to $\mathrm{CH}$ and use digital services at the $\mathrm{CH}$ website to access other companies' digital data. Further research is recommended to generalize the results to the whole population based on statistical analysis. Further, caution should be considered when comparing the findings with other studies in small businesses as the criteria for classifying small businesses differ across countries. Thus, the views of filers and users will be different from those in the UK. These limitations would be a fruitful area for further research. Future research should investigate the recent development of the Bank of England Electronic Data Submission (BEEDS) portal that was recently proposed and expected to be implemented by 2022 . 


\section{REFERENCES}

Adams, C. \& Frost, G. R. (2004) The development of corporate web-sites and implications for ethical, social and environmental reporting through these media. Edinburgh: Institute of Chartered Accountants of Scotland. https://www.icas.com /_data/assets/pdf_file/0005/159593/The-development-of-corporate-websites.pdf Accessed 2 October 2021.

Al-Hujran, O., Al-Lozi, E. M., Al-Debei, M. M., \& Maqableh, M. (2018). Challenges of cloud computing adoption from the TOE framework perspective. International Journal of E-Business Research (IJEBR), 14(3), 77-94. https://doi.org/10.4018/978-1-5225-8176-5.ch066

Alkhatib, E. A., Ojala, H., \& Collis, J. (2019). Determinants of the voluntary adoption of digital reporting by small private companies to Companies House: Evidence from the UK. International Journal of Accounting Information Systems, 34, 100421. https://doi.org/10.1016/j.accinf.2019.06.004

Azam, S., \& Taylor, D. (2013). Adopting standard business reporting in Australia: Are CFOs persuaded by technology attributes?. Management \& Accounting Review (MAR), 12(1), 27-54. http://dx.doi.org/10.24191/mar.v12i1.196

Baldwin, A. A., Brown, C. E., \& Trinkle, B. S. (2006). XBRL: An impacts framework and research challenge. Journal of Emerging Technologies in Accounting, 3(1), 97-116. https://doi.org/10.2308/jeta.2006.3.1.97

Bartley, J., Chen, A. Y. S., \& Taylor, E. (2010). Avoiding common errors of XBRL implementation. Journal of Accountancy, 209(2), 46-51. https://www.academia. edu/55975683/Avoiding_common_errors_of_XBRL_implementation Accessed 2 October 2021.

Bazeley, P., \& Jackson, K. (2013). Qualitative data analysis with NVivo: SAGE publications limited. London, the UK.

Bharosa, N., Janssen, M. F. W. H. A., Hulstijn, J., de Winne, N., \& van Wijk, R. (2011). Principles for transforming to Standard Business Reporting: Lessons learned from the Netherlands. In Proceedings of the 12th Annual International Conference on Digital Government Research. Association for Computing Machinery (ACM). 
Boritz, J. E., \& No, W. G. (2003). Assurance reporting for XBRL: XBRL (extensible assurance reporting language). Trust and data assurances in capital markets: the role of technology solutions, 22(3), 17-31. https://tarjomefa.com/wpcontent/uploads/2015/11/3216-English.pdf

Braun, V., \& Clarke, V. (2006). Using thematic analysis in psychology. Qualitative research in psychology, 3(2), 77-101. https://www.tandfonline.com/ doi/abs/10.1191/1478088706qp063oa Accessed 2 October 2021.

Bryman, A., \& Bell, E. (2015). Business research methods (Vol. 4th). Glasgow: Bell \& Bain Ltd.

Carter, P. (2006). Review of HMRC online services (Lord Carter of Coles). London:HMRC.https://webarchive.nationalarchives.gov.uk/ukgwa/200607190431 17/http:/www.hmrc.gov.uk/budget2006/carter-review.pdf Accessed 2 October 2021.

Collis, J., \& Hussey, R. (2014). Business research: A practical guide for undergraduate and postgraduate students. Macmillan International Higher Education. London, the UK

Collis, J., Alkhatib, E. \& de Cesare, S. (2018). Costs and benefits to small businesses of digital reporting. Association of Chartered Certified Accountants. https://www.accaglobal.com/gb/en/technical-activities/technical-resourcessearch/2018/january/-costs-and-benefits-to-small-companies-of-digitalreporting.html Accessed: 2 October 2021.

Companies House (2008) Companies House business plan 2008-2009. https://assets.publishing.service.gov.uk/government/uploads/system/uploads/attac hment_data/file/248247/0708.pdf Accessed 2 October 2021.

Companies House and HM Revenue \& Customs (2005). Aligning filing dates for companies. London: Joint Issue: Companies House and HM Revenue \& Customs. file:///C:/Users/user/Downloads/Aligning+company+filing+dates.pdf Accessed 2 October 2021.

Companies House (2013). XBRL company accounts. London: Companies House. https://ewf.companieshouse.gov.uk/xbrl Accessed 2 October 2021.

Companies House. (2015). Companies House business plan 2015-2016. https://www.gov.uk/government/publications/companies-house-business-plan2015-to-2016 Accessed 2 October 2021. 
Corbin, J., \& Strauss, A. (2008). Strategies for qualitative data analysis. Basics of Qualitative Research. Techniques and procedures for developing grounded theory, 3. Sage publications. https://dx.doi.org/10.4135/9781452230153.n4

Cordery, C. J., Fowler, C. J., \& Mustafa, K. (2011). A solution looking for a problem: factors associated with the non-adoption of XBRL. Pacific Accounting Review, 23 (1), 69-88. https://doi.org/10.1108/01140581111130634

Cox, D. R. (2006). Principles of statistical inference. Cambridge university press. https://doi.org/10.1017/CBO9780511813559

Daoud, H. (2019). Information Technology Investments and Productivity Changes in the Jordanian Banking Industry Between 1993-2015. Jordan Journal of Economic Sciences, 6(1), 99-118. https://doi.org/10.35516/1250-006-001-006 .

Debreceny, R., \& Gray, G. L. (1999). Financial reporting on the Internet and the external audit. European Accounting Review, 8(2), 335-350. http://dx.doi.org/10. 1080/096381899336078.

Debreceny, R., Farewell, S., Piechocki, M., Felden, C., \& Gräning, A. (2010). Does it add up? Early evidence on the data quality of XBRL filings to the SEC. Journal of Accounting and Public Policy, 29(3), 296-306. http://dx.doi.org/10.1016/ j.jaccpubpol.2010.04.001.

Department for Business Innovation \& Skills (BIS). (2009). Better regulation simplification plan 2009: Delivering a better business environment. https://webarchive.nationalarchives.gov.uk/20100104173841/http://www.berr.gov .uk/files/file53978.pdf Accessed 2 October 2021.

Department for Business, Energy \& Industrial Strategy (BEIS). (2020). Business Population Estimates for the UK and regions. https://www.gov.uk/government/ statistics/business-population-estimates-2020/business-population-estimates-forthe-uk-and-regions-2020-statistical-release-html Accessed 2 October 2021.

Deshmukh, A. (2004). Xbrl. The Communications of the Association for Information Systems, 13(1), 55. https://aisel.aisnet.org/cgi/viewcontent.cgi? article $=3235 \&$ context $=$ cais Accessed 2 October 2021 .

Doolin, B., \& Troshani, I. (2007). Organizational adoption of XBRL. Electronic Markets, 17(3), 199-209. https://doi.org/10.1080/10196780701503195 
Dunne, T., Helliar, C., Lymer, A ., \& Mousa, R. (2013). Stakeholder engagement in internet financial reporting: The diffusion of XBRL in the UK. The British Accounting Review, 45(3), 167-182. https://doi.org/10.1016/j.bar.2013.06.012

Dunne, T., Helliar, C., Lymer, A. \& Mousa, R. (2009). XBRL: The Views of the Stakeholders. Association of Chartered Certified Accountants. file:///C:/Users/hp/Downloads/rr-111-002\%20(1).pdf Accessed 2 October 2021.

Easterby-Smith, M., Thorpe, R., \& Jackson, P. R. (2012). Management research. Sage. London, the UK

Eierle, B., Ojala, H., \& Penttinen, E. (2014). XBRL to enhance external financial reporting: Should we implement or not? Case Company X. Journal of Accounting Education, 32(2), 160-170. https://doi.org/10.1016/j.jaccedu.2014.04.003

Financial Reporting Council (FRC). (2017). XBRL: Deep-dive: Digital future of corporate reporting. London: Financial Reporting Council. https://www.fsr.dk/ Files/Files/Dokumenter/Faglig/Regnskab/Internationalt/DigFutureXBRLDec.pdf $\backslash$ Accessed 2 October 2021.

Flick, U. (2002). Qualitative research-state of the art. Social science information, 41(1), 5-24. https://doi.org/10.1177/0539018402041001001

Garner, D., Henderson, D., Sheetz, S. D., \& Trinkle, B. S. (2013). The different levels of XBRL adoption. Management Accounting Quarterly, 14(2), 1-10.

Hampton, P. (2005). Reducing administrative burdens: effective inspection and enforcement, HM Treasury, March. https://www.smartreg.pe/reportes/ Hampton\%20Report.\%20Effective\%20inspection\%20and\%20enforcement $\% 2020$ 05.pdf Accessed 2 October 2021.

Heeks, R. (2006). Implementing and Managing e-Government. Thousand Oaks, California: Sage Publications.

Henderson, D., Sheetz, S. D., \& Trinkle, B. S. (2012). The determinants of interorganizational and internal in-house adoption of XBRL: A structural equation model. International journal of accounting information systems, 13(2), 109-140. https://doi.org/10.1016/j.accinf.2012.02.001

HM Revenue \& Customs (HMRC). (2009). Corporation tax 2009 No. 3218: The income and corporation taxes (electronic communications) (amendment) regulations 2009. Statutory Instruments. London. http://www.legislation.gov.uk/ uksi/2009/3218/pdfs/uksi_20093218_en.pdf Accessed 2 October 2021. 
HM Revenue \& Customs (HMRC). (2010). Duties of senior accounting officers of qualifying companies. London. http://webarchive.nationalarchives.gov.uk/ 20140109143644/http://www.hmrc.gov.uk/largecompanies/sao-qualifyingcompanies.pdf Accessed 2 October 2021.

HM Revenue \& Customs (HMRC). (2013). XBRL - When to tag, how to tag, what to tag. London. https://assets.publishing.service.gov.uk/government/uploads/ system/uploads/attachment_data/file/867135/XBRL_tagging.pdf Accessed 2 October 2021.

HM Revenue \& Customs (HMRC). (2015). Making tax digital. London: HM Revenue \& Customs. https://www.gov.uk/government/publications/making-taxdigital Accessed 2 October 2021.

Hulstijn, J., Van Wijk, R., De Winne, N., Bharosa, N., Janssen, M., \& Tan, Y. H. (2011, June). Public process management: a method for introducing standard business reporting. In Proceedings of the 12th annual international digital government research conference: Digital government innovation in challenging times (pp. 141-150).

Institute of Chartered Accountants in England and Wales (ICAEW). (2010). Implementing XBRL: A practical guide for accountants in business and practice. London. https://www.icaew.com/ /media/corporate/archive/files/technical/infor mation\%20technology/xbrl/implementing\%20xbrl.ashx Accessed 2 October 2021.

Jick, T. D. (1979). Mixing qualitative and quantitative methods: Triangulation in action. Administrative science quarterly, 24(4), 602-611. https://doi.org/ $10.2307 / 2392366$

Kindleberger, C. P. (1983). Standards as public, collective and private goods. IIES. https://doi.org/10.1111/j.1467-6435.1983.tb02705.x

KPMG. (2006). Administrative Burdens: HMRC Measurement Project. http://www.hmrc.gov.uk/better-regulation/kpmg1.pdf Accessed 2 October 2021.

Lakovic, T., Rondovic, B., Backovic-Vulic, T., \& Ivanovic, I. (2018). The determinants of xbrl adoption: An empirical study in an emerging economy. In European, Mediterranean, and Middle Eastern Conference on Information Systems (pp. 532-546). Springer, Cham

Lim, N., \& Perrin, B. (2014). Standard business reporting in Australia: Past, present, and future. Australasian Journal of Information Systems, 18(3). https://doi.org/10.3127/ajis.v18i3.895 
Lymer, A., \& Debreceny, R. (2003). The auditor and corporate reporting on the internet: challenges and institutional responses. International Journal of Auditing, 7(2), 103-120. http://dx.doi.org/10.1111/1099-1123.00063

Lymer, A., Debreceny, R., Gray, G., \& Rahman, A. (1999) Business reporting on the Internet. London: International Accounting Standards Committee. http://mail.cs.trinity.edu/ rjensen/Calgary/CD/iasb/busrepw.pdf Accessed 2 October 2021.

Lymer, A., Hansford, A., \& Pilkington, K. (2012). Developments in tax e-filing: practical views from the coalface. Journal of Applied Accounting Research, 13(3), 212-225. http://dx.doi.org/10.1108/09675421211281290

Madden, P. (2009). Standard business reporting: An idea whose time starts now. Economic Round-up, (3), 1-18. https://treasury.gov.au/sites/default/files/201903/1_SBR.rtf Accessed 2 October 2021.

Mahler, A., \& Rogers, E. M. (1999). The diffusion of interactive communication innovations and the critical mass: the adoption of telecommunications services by German banks. Telecommunications policy, 23(10-11), 719-740. http://dx.doi.org/10.1016/S0308-5961(99)00052-X

Miles, M. B. \& Huberman, A. M. (1994) An expanded sourcebook: Qualitative data analysis. Thousands Oaks: Sage.

Miller, G. (2013). Standard business reporting-improving business reporting now and into the future. Keeping Good Companies, 65(2), 70-74. https://search.informit.org/doi/10.3316/INFORMIT.194884802404390 Accessed 2 October 2021.

Mousa, R. (2011) E-government adoption process: XBRL adoption in HM revenue and customs and Companies House. Unpublished PhD Thesis. University of Birmingham.

Mousa, R. (2013a). E-Government adoption in the UK: XBRL project. International Journal of Electronic Government Research (IJEGR), 9(2), 101-119. https://doi.org/10.4018/jegr.2013040106

Mousa, R. (2013b). E-government challenges at the UK's customs and tax department. Electronic Government, an International Journal, 10(1), 86-103. https://doi.org/10.1504/eg.2013.051277 
Ojala, H., Penttinen, E., Collis, J., \& Virtanen, T. H. (2018). Design principles for Standard Business Reporting (SBR) taxonomy development: Evidence from Finland. Nordic Journal of Business, 67(1), 4-26.

Oliveira, T., \& Martins, M. F. (2011). Literature review of information technology adoption models at firm level. Electronic Journal of Information Systems Evaluation, 14(1), 110.

Pinsker, R., \& Li, S. (2008). Costs and benefits of XBRL adoption: Early evidence. Communications of the ACM, 51(3), 47-50. https://doi.org/10.1145/1325555. 1325565

Plumlee, R. D., \& Plumlee, M. A. (2008). Assurance on XBRL for financial reporting. Accounting Horizons, 22(3), 353-368.. http://dx.doi.org/10.2308/ acch.2008.22.3.353

Plumlee, R. D., \& Plumlee, M. A. (2008). Assurance on XBRL for financial reporting. Accounting Horizons, 22(3), 353-368. https://doi.org/10.2139/ssrn. 1104245

Robb, D. A., Rohde, F. H., \& Green, P. F. (2016). Standard Business Reporting in Australia: efficiency, effectiveness, or both?. Accounting \& Finance, 56(2), 509544. https://doi.org/10.1111/acfi.12094

Rogers, E.M. (1995). Diffusion of innovations (4th ed.). New York, NY: Free Press.

Rostami, M., \& Nayeri, M. D. (2015). Investigation on XBRL adoption based on the TOE model. Journal of Economics, Management and Trade, 7(4). 269-278. https://doi.org/10.9734/bjemt/2015/16879

Sinnett, W. M., \& Willis, M. (2009). The time is right for Standard Business Reporting: the concept of common compliance requirements for all regulatory reporting and legislation is gaining steam. Who's on board? What steps are being taken? What's expected?. Financial Executive, 25(9), 23-28. https://go.gale.com/ps/i.do?id=GALE\%7CA213388063\&sid=googleScholar\&v=2 $.1 \& \mathrm{it}=\mathrm{r} \&$ linkaccess $=$ abs\&issn $=08954186 \& \mathrm{p}=\mathrm{AONE} \& \mathrm{sw}=\mathrm{w} \&$ userGroupName $=\mathrm{a}$ non\%7E9063ef8c Accessed 2 October 2021.

Srivastava, R. P., \& Kogan, A. (2010). Assurance on XBRL instance document: A conceptual framework of assertions. International Journal of Accounting Information Systems, 11(3), 261-273. http://dx.doi.org/10.1016/j.accinf.2010. 07.019 
The European Securities and Markets Authority (ESMA). (2020). ESMA publishes 2020 ESEF XBRL Taxonomy files and ESEF Conformance suite. https://www.esma.europa.eu/press-news/esma-news/esma-publishes-2020-esefxbrl-taxonomy-filesand-esef-conformance-suite Accessed 2 October 2021.

The European Securities and Markets Authority (ESMA). (2021). ESMA in Brief. https://www.esma.europa.eu/about-esma/esma-in-brief Accessed 2 October 2021.

The Organization for Economic Cooperation and Development (OECD). (2009). Forum on Tax Administration: Taxpayer Services Sub-Group, Guidance Note Standard Business Reporting. Centre for Tax Policy and Administration. http://www.oecd.org/tax/administration/43384923.pdf Accessed 2 October 2021.

Thong, J. Y. (1999). An integrated model of information systems adoption in small businesses. Journal of management information systems, 15(4), 187-214. https://doi.org/10.1080/07421222.1999.11518227

Tornatzky, L. G., \& Fleischer, M. (1990). The process of technology innovation. Lexington, MA: Lexington Books. https://doi.org/10.1007/BF02371446

Troshani, I., \& Rao, S. (2007). Drivers and inhibitors to XBRL adoption: A qualitative approach to building a theory in under-researched areas. International Journal of E-Business Research (IJEBR), 3(4), 98-111. https://doi.org/10.4018/ jebr.2007100106

Troshani, I., Parker, L. D., \& Lymer, A. (2015). Institutionalising XBRL for financial reporting: resorting to regulation. Accounting and Business Research, 45(2), 196-228. https://doi.org/10.1080/00014788.2014.980772

Van Maanen, J. (1979). Qualitative Methods Reclaimed. Administrative Science Quarterly, 24(4), 520-526. https://doi.org/10.2307/2392358

Vasarhelyi, M. A., Chan, D. Y., \& Krahel, J. P. (2012). Consequences of XBRL standardization on financial statement data. Journal of Information Systems, 26(1), 155-167. https://doi.org/10.2308/isys-10258

Vasileiou, K., Barnett, J., Thorpe, S., \& Young, T. (2018). Characterising and justifying sample size sufficiency in interview-based studies: systematic analysis of qualitative health research over a 15-year period. BMC medical research methodology, 18(1), 1-18. http://dx.doi.org/10.1186/s12874-018-0594-7 
Zhu, K., Dong, S., Xu, S. X., \& Kraemer, K. L. (2006). Innovation diffusion in global contexts: Determinants of the post-adoption digital transformation of European companies. European Journal of Information Systems, 15(6), 601-616. https://doi.org/10.1057/palgrave.ejis.3000650 


\section{Appendix A}

\section{SBR/XBRL innovation diffusion studies based on the TOE Framework}

\begin{tabular}{|c|c|c|c|c|c|c|}
\hline \multirow{2}{*}{$\begin{array}{l}\text { Author(s) } \\
\text { and date }\end{array}$} & \multirow{2}{*}{$\begin{array}{c}\text { Other } \\
\text { theoretical } \\
\text { bases }\end{array}$} & \multicolumn{3}{|c|}{ Analyzed Variables } & \multirow{2}{*}{$\begin{array}{l}\begin{array}{l}\text { Data } \\
\text { collection }\end{array} \\
\text { Samplel } \\
\text { Country of } \\
\text { study }\end{array}$} & \multirow{2}{*}{$\begin{array}{l}\text { Analysis } \\
\text { methods }\end{array}$} \\
\hline & & Technological context & $\begin{array}{l}\text { Organizational } \\
\text { context }\end{array}$ & $\begin{array}{l}\text { Environmental } \\
\text { context }\end{array}$ & & \\
\hline $\begin{array}{l}\text { Doolin and } \\
\text { Troshani } \\
(2007)\end{array}$ & $\begin{array}{l}\text { Stakeholder } \\
\text { and Social } \\
\text { network } \\
\text { theory }\end{array}$ & $\begin{array}{l}\text { Relative advantage* } \\
\text { Complexity* } \\
\text { Trialability/ } \\
\text { Observability* } \\
\text { Stability* }\end{array}$ & $\begin{array}{l}\text { Innovation } \\
\text { champion* }\end{array}$ & $\begin{array}{l}\begin{array}{l}\text { Market } \\
\text { condition* }\end{array} \\
\text { Trading Partner* } \\
\text { Accessible } \\
\text { information* } \\
\text { Critical mass* } \\
\text { Existing } \\
\text { support* }\end{array}$ & $\begin{array}{l}11 \text { interviews } \\
\text { / Australia }\end{array}$ & $\begin{array}{l}\text { Thematic } \\
\text { approach }\end{array}$ \\
\hline $\begin{array}{l}\text { Troshani } \\
\text { and Rao } \\
(2007)\end{array}$ & - & $\begin{array}{l}\text { Perceived relative } \\
\text { advantage and } \\
\text { benefits* } \\
\text { Perceived costs* } \\
\text { Compatibility* } \\
\text { Trialability* } \\
\text { Observability* } \\
\text { Complexity* } \\
\text { Instability of the } \\
\text { XBRL specification* }\end{array}$ & $\begin{array}{l}\text { Human capital and } \\
\text { employee } \\
\text { education* } \\
\text { Management } \\
\text { attitudes* } \\
\text { Education and } \\
\text { training* } \\
\text { Lack of resources } \\
\text { and expertise * }\end{array}$ & $\begin{array}{l}\text { External } \\
\text { pressures* } \\
\text { Culture* } \\
\text { Legal issues* } \\
\text { Industry } \\
\text { associations* } \\
\text { Successful } \\
\text { adoptions* } \\
\text { Government } \\
\text { mandates* } \\
\text { A “wait and see” } \\
\text { approach* }\end{array}$ & $\begin{array}{l}11 \text { interviews/ } \\
\text { Australia }\end{array}$ & $\begin{array}{l}\text { Thematic } \\
\text { approach }\end{array}$ \\
\hline $\begin{array}{l}\text { Cordery et } \\
\text { al. (2011) }\end{array}$ & DOI theory & $\begin{array}{l}\text { Relative advantage* } \\
\text { Compatibility* } \\
\text { Complexity* } \\
\text { Trialability* }\end{array}$ & $\begin{array}{l}\text { Top management } \\
\text { support* } \\
\text { Organization } \\
\text { champion* } \\
\text { Organization size } \\
\text { and resources* }\end{array}$ & $\begin{array}{l}\text { Trading } \\
\text { partners* } \\
\text { Regulators and } \\
\text { government* } \\
\text { Market } \\
\text { competition* }\end{array}$ & $\begin{array}{l}6 \text { interviews/ } \\
\text { New Zealand }\end{array}$ & $\begin{array}{l}\text { Multivariate } \\
\text { analysis } \\
\text { structural } \\
\text { equation } \\
\text { modelling }\end{array}$ \\
\hline
\end{tabular}




\begin{tabular}{|c|c|c|c|c|c|c|}
\hline \multirow{2}{*}{$\begin{array}{l}\text { Author(s) } \\
\text { and date }\end{array}$} & \multirow{2}{*}{$\begin{array}{c}\text { Other } \\
\text { theoretical } \\
\text { bases }\end{array}$} & \multicolumn{3}{|c|}{ Analyzed Variables } & \multirow{2}{*}{$\begin{array}{l}\begin{array}{l}\text { Data } \\
\text { collection }\end{array} \\
\text { Samplel } \\
\text { Country of } \\
\text { study }\end{array}$} & \multirow{2}{*}{$\begin{array}{l}\text { Analysis } \\
\text { methods }\end{array}$} \\
\hline & & Technological context & $\begin{array}{l}\text { Organizational } \\
\text { context }\end{array}$ & $\begin{array}{l}\text { Environmental } \\
\text { context }\end{array}$ & & \\
\hline & & & & $\begin{array}{l}\text { accessibility of } \\
\text { information* }\end{array}$ & & \\
\hline $\begin{array}{l}\text { Henderson } \\
\text { et al. (2012) }\end{array}$ & $\begin{array}{l}\text { DOI theory } \\
\text { and } \\
\text { institutional } \\
\text { theory }\end{array}$ & $\begin{array}{l}\text { Relative advantage* } \\
\text { Compatibility* } \\
\text { Complexity* }\end{array}$ & $\begin{array}{l}\text { Expertise } \\
\text { Learning from } \\
\text { external sources* }\end{array}$ & $\begin{array}{l}\text { Mimetic } \\
\text { pressure } \\
\text { Coercive } \\
\text { pressure } \\
\text { Normative } \\
\text { pressure }\end{array}$ & $\begin{array}{l}65 \text { survey/ } \\
\text { Cross } \\
\text { countries }\end{array}$ & $\begin{array}{l}\text { Factor } \\
\text { analysis, } \\
\text { multiple } \\
\text { regressions }\end{array}$ \\
\hline $\begin{array}{l}\text { Azam and } \\
\text { Taylor } \\
(2013)\end{array}$ & DOI theory & $\begin{array}{l}\text { Relative advantage } \\
\text { Compatibility* } \\
\text { Complexity* }\end{array}$ & - & $\begin{array}{l}\text { Competitive } \\
\text { pressure } \\
\text { Government } \\
\text { pressure }\end{array}$ & $\begin{array}{l}\text { 54 Survey } \\
\text { questionnaire } \\
\text { s/ } \\
\text { Australia }\end{array}$ & $\begin{array}{l}\text { Thematic } \\
\text { approach }\end{array}$ \\
\hline $\begin{array}{l}\text { Dunne et al. } \\
(2013)\end{array}$ & DOI theory & $\begin{array}{l}\text { Relative advantages* } \\
\text { compatibility* } \\
\text { XBRL complexity* }\end{array}$ & $\begin{array}{l}\text { IT Skills and } \\
\text { Expertise* } \\
\text { Formalization* }\end{array}$ & $\begin{array}{l}\text { XBRL mandate* } \\
\text { Critical mass* } \\
\text { Access to } \\
\text { external support } \\
\text { and information* }\end{array}$ & $\begin{array}{l}\text { Case study } \\
153 \text { survey/ } \\
\text { The UK }\end{array}$ & $\begin{array}{l}\text { Thematic } \\
\text { approach }\end{array}$ \\
\hline $\begin{array}{l}\text { Mousa } \\
(2013 a)\end{array}$ & DOI theory & $\begin{array}{l}\text { Relative advantages* } \\
\text { compatibility* } \\
\text { XBRL complexity* }\end{array}$ & $\begin{array}{l}\text { IT Skills and } \\
\text { Expertise* } \\
\text { Formalization* }\end{array}$ & $\begin{array}{l}\text { XBRL mandate* } \\
\text { Critical mass* } \\
\text { Access to } \\
\text { external support } \\
\text { and information* }\end{array}$ & $\begin{array}{l}\text { Case study- } \\
\text { HMRC } \\
3 \text { interviews/ } \\
\text { The UK }\end{array}$ & $\begin{array}{l}\text { Thematic } \\
\text { approach }\end{array}$ \\
\hline $\begin{array}{l}\text { Mousa } \\
(2013 b)\end{array}$ & DOI theory & $\begin{array}{l}\text { Relative advantages* } \\
\text { compatibility* } \\
\text { XBRL complexity* }\end{array}$ & $\begin{array}{l}\text { IT Skills and } \\
\text { Expertise* } \\
\text { Formalization* }\end{array}$ & $\begin{array}{l}\text { XBRL mandate* } \\
\text { Critical Mass* } \\
\text { Access to } \\
\text { external support } \\
\text { and information* }\end{array}$ & $\begin{array}{l}\text { Case study- } \\
\mathrm{CH} \\
4 \text { interviews/ } \\
\text { The UK }\end{array}$ & $\begin{array}{l}\text { A meta- } \\
\text { analysis of the } \\
\text { existing } \\
\text { SBR/XBRL } \\
\text { literature }\end{array}$ \\
\hline
\end{tabular}




\begin{tabular}{|c|c|c|c|c|c|c|}
\hline \multirow{2}{*}{$\begin{array}{l}\text { Author }(s) \\
\text { and date }\end{array}$} & \multirow{2}{*}{$\begin{array}{c}\text { Other } \\
\text { theoretical } \\
\text { bases }\end{array}$} & \multicolumn{3}{|c|}{ Analyzed Variables } & \multirow{2}{*}{$\begin{array}{l}\begin{array}{l}\text { Data } \\
\text { collection }\end{array} \\
\text { Samplel } \\
\text { Country of } \\
\text { study }\end{array}$} & \multirow{2}{*}{$\begin{array}{l}\text { Analysis } \\
\text { methods }\end{array}$} \\
\hline & & Technological context & $\begin{array}{l}\text { Organizational } \\
\text { context }\end{array}$ & $\begin{array}{l}\text { Environmental } \\
\text { context }\end{array}$ & & \\
\hline $\begin{array}{l}\text { Lim and } \\
\text { Perrin } \\
(2014)\end{array}$ & DOI theory & $\begin{array}{l}\text { Relative advantage* } \\
\text { Compatibility* } \\
\text { Complexity* } \\
\text { Trialability* } \\
\text { Observability* } \\
\text { Perceived Costs* } \\
\text { SBR forms and } \\
\text { reports quality* }\end{array}$ & $\begin{array}{l}\text { Financial } \\
\text { resources* } \\
\text { Expertise* } \\
\text { Top management } \\
\text { support* }\end{array}$ & $\begin{array}{l}\begin{array}{l}\text { External } \\
\text { pressure* }\end{array} \\
\text { External } \\
\text { support* }\end{array}$ & $\begin{array}{l}\text { Conceptual } \\
\text { paper/ } \\
\text { Australia }\end{array}$ & $\begin{array}{l}\text { Confirmatory } \\
\text { factor analysis }\end{array}$ \\
\hline $\begin{array}{l}\text { Rostami and } \\
\text { Nayeri } \\
(2015)\end{array}$ & & $\begin{array}{l}\text { Easy understanding } \\
\text { and fluency of } \\
\text { system* }\end{array}$ & $\begin{array}{l}\text { The successful } \\
\text { implementation } \\
\text { of innovation * } \\
\text { existing human and } \\
\text { financial } \\
\text { resources* } \\
\text { Manpower skills } \\
\text { and experience* }\end{array}$ & 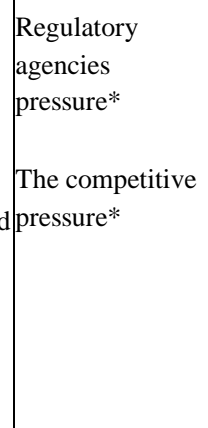 & $\begin{array}{l}\text { Survey } \\
118 \text { survey/ } \\
\text { NA }\end{array}$ & $\begin{array}{l}\text { Explorative } \\
\text { factor analysis }\end{array}$ \\
\hline $\begin{array}{l}\text { Lakovic et } \\
\text { al. (2018) }\end{array}$ & \begin{tabular}{|l} 
Institutional \\
theory
\end{tabular} & $\begin{array}{l}\text { IT infrastructure } \\
\text { ICT integration } \\
\text { ICT expertise }\end{array}$ & $\begin{array}{l}\text { Economic } \\
\text { expectations } \\
\text { Inter-sectoral } \\
\text { expectations } \\
\text { Inter- } \\
\text { organizational } \\
\text { expectation }\end{array}$ & $\begin{array}{l}\text { Mimetic } \\
\text { pressure } \\
\text { Coercive } \\
\text { pressure* }\end{array}$ & $\begin{array}{l}50 \text { survey/ } \\
\text { Montenegro }\end{array}$ & $\begin{array}{l}\text { Multivariate } \\
\text { analysis } \\
\text { structural } \\
\text { equation } \\
\text { modelling }\end{array}$ \\
\hline $\begin{array}{l}\text { Alkhatib et } \\
\text { al. (2019) }\end{array}$ & DOI theory & $\begin{array}{l}\text { Relative advantage* } \\
\text { Compatibility } \\
\text { Complexity* } \\
\text { Costs* }\end{array}$ & $\begin{array}{l}\text { Technology } \\
\text { competence* }\end{array}$ & Network effect & $\begin{array}{l}343 \text { members } \\
\text { of ACCA in } \\
\text { the UK }\end{array}$ & \begin{tabular}{|l} 
Multivariate \\
analysis \\
structural \\
equation \\
modelling
\end{tabular} \\
\hline
\end{tabular}




\section{Appendix B}

\section{Previous studies identified the costs and benefits of XBRL}

Author(s) and date

Costs and benefits analysis

Benefits/advantages

Costs/ disadvantages
Analysis

methods
Data collection

Sample

Country of study

Interview survey

4 large companies

adopted XBRL

Canada, Germany, South Africa and the USA

Questionnaire survey

173 key stakeholders: auditors, accountants, tax practitioners, and users of financial information

Little software available for displaying and analysing

XBRL data

The UK without losing

integrity

Enhances the reliability of data

Integrates easily with other applications

Offers more analytical tool

Garner et al. (2013)
Facilitates continuous auditing

Facilitates preparing financial statements

Improves the internal controls

Improves decision making
Implementing XBRL Descriptive consumed a large portion of statistics our organization's accounting budget
Questionnaire survey

344 companies

Response rate (28\%)

Africa, Asia, Europe, Middle East and North America 


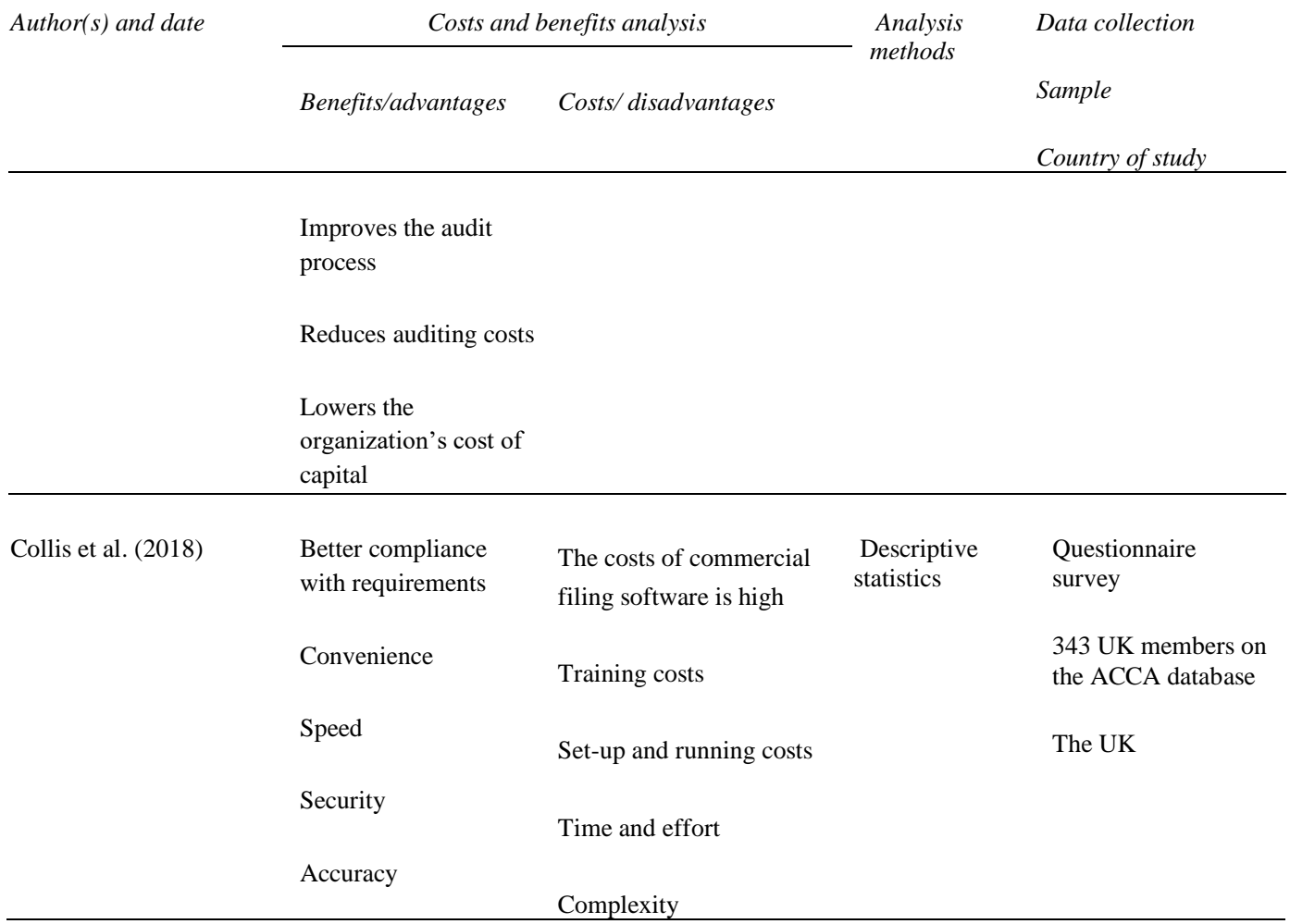




\section{Appendix C}

\section{Interviews details}

\begin{tabular}{|c|c|c|c|c|}
\hline Interviewee \# & $\begin{array}{l}\text { Job } \\
\text { title/position }\end{array}$ & Organization & Main activities & Date \\
\hline 1 & $\begin{array}{l}\text { Assistant } \\
\text { manager }\end{array}$ & HMRC & $\begin{array}{l}\text { Receiving corporations tax returns from } \\
\text { small businesses in iXBRL format }\end{array}$ & 2016 \\
\hline 2 & $\begin{array}{l}\text { Head of digital } \\
\text { accounts }\end{array}$ & $\begin{array}{l}\text { Companies } \\
\text { House }\end{array}$ & $\begin{array}{l}\text { Receiving the statutory accounts and } \\
\text { annual returns from small businesses in } \\
\text { XBRL/iXBRL formats }\end{array}$ & 2016 \\
\hline 3 & Head of accounts & $\begin{array}{l}\text { Digital filing } \\
\text { software provider } \\
\text { A }\end{array}$ & $\begin{array}{l}\text { Responsible for converting companies' } \\
\text { accounts and returns from Word and Excel } \\
\text { to digital iXBRL formats }\end{array}$ & 2016 \\
\hline 4 & $\begin{array}{l}\text { Senior } \\
\text { accountant }\end{array}$ & $\begin{array}{l}\text { Digital filing } \\
\text { software provider } \\
\text { B }\end{array}$ & $\begin{array}{l}\text { Responsible for filing the annual returns in } \\
\text { iXBRL formats with } \mathrm{CH} \text { and using the } \\
\text { digital services at the } \mathrm{CH} \text { website to } \\
\text { access other companies' digital data }\end{array}$ & 2016 \\
\hline 5 & $\begin{array}{l}\text { Strategy } \\
\text { architect in } \\
\text { HMRC e- } \\
\text { services }\end{array}$ & $\begin{array}{l}\text { External } \\
\text { consultant of } \\
\text { HMRC digital } \\
\text { filing } \\
\end{array}$ & $\begin{array}{l}\text { Participating in the development of } \\
\text { iXBRL at HMRC since } 2005\end{array}$ & 2016 \\
\hline $6,7,8,9$ & $\begin{array}{l}\text { Qualified } \\
\text { accountants and } \\
\text { auditors }\end{array}$ & $\begin{array}{l}\text { Accountancy } \\
\text { firm A }\end{array}$ & $\begin{array}{l}\text { Filing statutory accounts and returns in } \\
\text { paper and digital formats for small } \\
\text { businesses at } \mathrm{CH} \text { and } \mathrm{HMRC} \text {, and using }\end{array}$ & 2016 \\
\hline $10^{*}, 11,12$ & $\begin{array}{l}\text { Qualified } \\
\text { accountant }\end{array}$ & $\begin{array}{l}\text { Accountancy } \\
\text { firm B }\end{array}$ & $\begin{array}{l}\text { the digital services at the } \mathrm{CH} \text { website to } \\
\text { access other companies' digital data }\end{array}$ & 2016 \\
\hline $13^{*}, 14$ & $\begin{array}{l}\text { Qualified } \\
\text { accountants }\end{array}$ & Small business A & & 2016 \\
\hline 15 & $\begin{array}{l}\text { Qualified } \\
\text { accountant }\end{array}$ & Small business B & & 2016 \\
\hline 16 & $\begin{array}{l}\text { Qualified } \\
\text { accountant }\end{array}$ & Small business $\mathrm{C}$ & & 2016 \\
\hline 17,18 & $\begin{array}{l}\text { Qualified } \\
\text { accountant }\end{array}$ & Small business D & & 2021 \\
\hline 19 & $\begin{array}{l}\text { Qualified } \\
\text { accountant }\end{array}$ & $\begin{array}{l}\text { Accountancy } \\
\text { firm C }\end{array}$ & & 2021 \\
\hline
\end{tabular}

\footnotetext{
*Interviewees who participated in two stages of the interviews; 2016 and 2021.
} 